\title{
PROSES BERPIKIR SISWA DALAM MEMECAHKAN MASALAH MATEMATIKA KONTEKSTUAL DITINJAU DARI KEMAMPUAN MATEMATIKA DAN JENIS KELAMIN
}

\author{
Aulia Rohmatul Hidayah \\ Program Studi Pendidikan Matematika, FMIPA, Universitas Negeri Surabaya \\ auliarohmatulhidayah@gmail.com \\ Rooselyna Ekawati \\ Program Studi Pendidikan Matematika, FMIPA, Universitas Negeri Surabaya \\ rooselynaekawati@unesa.ac.id
}

\begin{abstract}
Abstrak
Matematika sebagai mata pelajaran penting di kurikulum sekolah, memiliki objek kajian abstrak berupa mental dan pikiran, yang dapat diketahui melalui proses berpikir siswa ketika dihadapkan suatu permasalahan. Penelitian ini bertujuan mendeskripsikan proses berpikir siswa dalam memecahkan masalah matematika kontekstual ditinjau dari kemampuan matematika dan jenis kelamin pada materi persamaan linear dua variabel (SPLDV) kelas VIII. Metode yang digunakan deskriptif kualitatif. Subjek diambil dari 50 siswa yang diberikan tes kemampuan matematika. Melalui hasil tes, diperoleh 3 siswa laki-laki dan 3 siswa perempuan, dengan kategori kemampuan matematika tinggi, sedang dan rendah. Hasil penelitian memperlihatkan siswa laki-laki dan perempuan berkemampuan matematika tinggi melakukan semua tahap proses berpikir, yaitu menerima, menyimpan, mengolah, dan memanggil kembali informasi disetiap tahap pemecahan masalah. Siswa laki-laki berkemampuan matematika sedang tidak memanggil kembali informasi saat memahami masalah, tidak mengolah informasi saat melaksanakan rencana penyelesaian, dan tidak melakukan tahap memeriksa kembali. Sedangkan siswa perempuan tidak memanggil kembali informasi saat memahami masalah dan tidak mengolah informasi pada tahap memeriksa kembali. Siswa laki-laki berkemampuan matematika rendah saat memahami masalah melakukan proses menerima, menyimpan, mengolah, dan memanggil kembali informasi, dan pada tahap memeriksa kembali melakukan proses memanggil kembali informasi. Sedangan siswa perempuan tidak memanggil kembali informasi saat memahami masalah, dan tidak mengolah informasi saat merencakan penyelesaian. Urutan tahapan dan proses berpikir masing-masing siswa berbeda. Melalui perbedaan tersebut, guru diharapkan dapat mengenali proses berpikir dan urutan yang dilakukan siswa serta menerapkan metode pembelajaran yang sesuai proses berpikir siswa pada masing-masing kategori kemampuan matematika dan jenis kelamin, sehingga siswa dapat meningkatkan kemampuan berpikir matematika.
\end{abstract}

Kata Kunci: Proses Berpikir, Pemecahan Masalah Kontekstual, Kemampuan matematika, Jenis Kelamin

\begin{abstract}
Mathematics as an important subject in the school curriculum, has an abstract object of study in the form of mental and mind, which can be known through students' thought processes when faced with a problem. This study aimed to determine the students' cognition process in solving mathematics contextual problems in terms of mathematical abilities and gender in the material of two-variable linear equations (SPLDV) in class VIII at SMPN 2 Mojokerto. This research method is qualitative descriptive. Subjects were taken from 50 students who were given a math ability test. Through the test results, obtained 3 male students and 3 female students, with the category of high, medium and low math ability. The results showed male and female students with high math abilities did all stages of the thinking process, that is receiving, storing, processing, and recalling information at each stage of problem solving. Male students with mathematical abilities are not recalling information when they understand a problem, didn't process information when carrying out the completion plan, and didn't carry out the rechecking stage. Meanwhile, female students didn't recall information when they understood the problem and did not process information at the rechecking stage. Male students with low math abilities when understanding the problem carry out the process of receiving, storing, processing, and recalling information, and at the re-checking stage carrying out the process of recalling information. Meanwhile, female students did not recall information when they understood problems, and didn't process information when planning solutions. The sequence of stages and thought processes of each student is different. Through these differences, teachers are expected to be able to recognize the thought processes and sequences carried out by students and apply learning methods that are appropriate to students'
\end{abstract}


thinking processes in each category of math ability and gender, so that students can improve their mathematical thinking skills.

Keywords: Thinking Process, Contextual Problem Solving, Mathematical Abilities, Gender

\section{PENDAHULUAN}

Matematika dianggap sebagai mata pelajaran penting dalam kurikulum sekolah. Menurut Soedjadi (2000) matematika mempelajari objek kajian yang abstrak, dalam bentuk mental atau pikiran, yang tidak dapat terlihat hanya dengan hasil belajar siswa, namun perlu juga mengamati cara belajar siswa (Fajriati, 2019). Berkaitan dengan cara belajar siswa, menurut Panjaitan (2016) belajar diartikan sebagai kegiatan yang berkaitan dengan proses berpikir, proses berpikir didefinisikan sebagai aktivitas di dalam pikiran siswa mencakup menerima informasi, mengolah informasi, menyimpan informasi, dan memanggil kembali informasi dari ingatan saat dibutuhkan. Empat aktivitas mental yang disebutkan sebelumnya merupakan pemrosesan informasi yang bekerja sebagai suatu sistem. Menurut Slavin (2006) teori pemrosesan informasi merupakan teori kognitif yang menggambarkan proses penyimpanan, dan pemanggilan kembali dari pikiran manusia. Adapun bagan pemrosesan informasi menurut Slavin (2006) sebagai berikut;

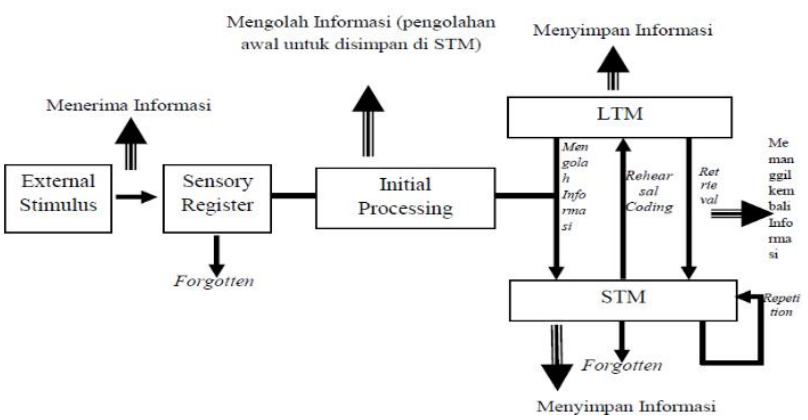

Gambar 1.1 Teori Pemrosesan Informasi (Slavin 2006, hal. 167)

Solso (2008) mengungkapkan bahwa ketika menghadapi sebuah permasalahan, seseorang akan berpikir, sehingga proses berpikir siswa dapat terlihat melalui langkah-langkah penyelesaiannya. Mengetahui proses berpikir siswa berguna untuk mengungkapkan kesalahan berpikir yang terjadi dan memperbaiki pengetahuannya. Berkaitan dengan proses berpikir hal yang berperan penting adalah pemecahan masalah, sesuai dengan pernyataan Schunk (2012 : 299) dalam Fajriati, 2019, "One of the most important types of cognitive processing that occurs often during learning is problem solving" (Fajriati, 2019). Polya mengatakan pemecahan masalah adalah usaha untuk mencari jalan keluar ketika menghadapi kesulitan untuk mencapai tujuan yang tidak mudah dicapai (Asfar, A.I.T dan Syarif Nur, 2018). Kurikulum matematika di Indonesia saat ini, secara eksplisit menjadikan pemecahan masalah sebagai tujuan pembelajaran matematika (Syafitri T et al., 2016). Hal senada sesuai rumusan NCTM (2000) terdapat lima standar proses yang berkaitan dengan pembelajaran, salah satunya adalah pemecahan masalah (problem solving).

Menurut Polya (1973) terdapat empat tahap pemecahan masalah yaitu (1) memahami masalah adalah mengidentifikasi informasi yang diketahui, mengetahui apa saja yang ada, hubungan, juga nilai-nilai terkait yang dibutuhkan ; (2) merancang rencana penyelesaian adalah mengidentifikasi masalah yang dengan mengetahui operasi atau strategi yang akan digunakan dalam penyelesaian masalah; (3) melaksanakan rencana penyelesaian adalah menerapkan dan mempertahankan rencana penyelesaian yang telah disusun, serta melaksanakan strategi ketika proses penyelesaian; dan (4) memeriksa kembali adalah melakukan evaluasi terhadap langkah-langkah penyelesaian yang telah dilakukan, mempertimbangkan apakah solusi maupun langkah yang diperoleh logis dan efektif serta menjawab pertanyaan pada masalah yang diberikan. Silver (1982) dalam (Syafitri T et al., 2016) menyatakan bahwa siswa dapat memantau dan mengevaluasi proses berpikir mereka sendiri melalui tahap-tahap penyelesaian masalah yang dilakukan. Mengingat pentingnya pemecahan masalah matematika, pada kenyatannya kemampuan pemecahan masalah matematika siswa Indonesia masuk kategori rendah. Menurut Parulian (2019) rendahnya kemampuan pemecahan masalah matematika siswa disebabkan kurang terlatihnya siswa mengerjakan soal non-rutin. Berdasarkan hal tersebut, penting untuk mengedepankan pemecahan masalah matematika dalam pembelajaran untuk mengembangkan dan melatih kemampuan pemecahan masalah (Rosyada, 2018). Selain pemecahan masalah, matematika juga memiliki peran penting bagi kehidupan manusia dalam membantu mengantisipasi, merencanakan, memutuskan, dan menyelesaikan masalah di kehidupan sehari-hari. Masalah matematika yang mengaitkan dengan kehidupan sehari-hari yaitu masalah kontekstual (Jayanti et al., 2018). Gravemeijer dan Doorman (1999) mengartikan masalah kontekstual yaitu masalah yang melukiskan situasi dunia nyata yang pernah dialami siswa, dimana masalah tersebut akan dirumuskan dalam konteks tertentu kemudian siswa diharapkan dapat menerapkan pengetahuan matematika untuk menyelesaikan masalah. Peran masalah kontekstual dalam pemecahan masalah matematika yaitu untuk mengangkat motivasi siswa agar mampu terlibat aktif saat memecahkan masalah karena sesuai pengalaman dan dekat dengan lingkungan siswa. Pada penelitian ini, soal kontekstual yang digunakan merupakan situasi personal atau pribadi yang berkaitan dengan kehidupan sehari-hari siswa, baik di rumah 
bersama keluarga, maupun bersama teman-temannya. Konteks yang digunakan adalah konteks Dress-up. Konteks Dress-up (Kamuflase) merupakan soal yang diubah menggunakan bahasa cerita sehingga terlihat memiliki konteks atau situasi (De Lange 1987). Penelitian yang relevan dilakukan oleh Alifah \& Aripin (2018) mengenai proses berpikir siswa dalam memecahkan masalah matematik berdasarkan gaya kognitif field dependent dan field independent, namun penelitian tersebut belum menggunakan masalah matematika yang lebih spesifik untuk masalah kontekstual dengan situasi personal atau pribadi dan konteks Dress-Up. Penggunaan masalah kontekstual pada pemecahan masalah matematika berperan dalam meningkatkan motivasi siswa sehingga mampu terlibat aktif saat memecahkan suatu masalah yang dekat dengan lingkungan serta pengalamannya. Salah satu materi matematika yang berkaitan erat dengan masalah kontekstual adalah sistem persamaan linear dua variabel (SPLDV), dalam kurikulum 2013, satu kompetensi yang harus dikuasai oleh siswa kelas 8 sekolah menengah pertama (SMP) adalah SPLDV.

Ketika memecahkan masalah, setiap siswa memiliki cara berbeda. Hal ini dikarenakan kemampuan matematika yang dimiliki juga berbeda (Sukmawati, 2015). Berkaitan dengan hal tersebut, proses berpikir yang dilakukan siswa juga dapat berbeda bergantung dengan kemampuan matematika yang dimiliki. Menurut Nurman (2008) proses penyelesaian masalah siswa dapat dipengaruhi oleh kemampuan matematika yang dimiliki. Siswa cenderung mampu menyelesaikan masalah matematika dengan benar, ketika memiliki kemampuan matematika tinggi, sedangkan siswa dengan kemampuan rendah ketika menyelesaikan masalah, hasil yang didapatkan cenderung kurang benar.

Selain faktor kemampuan matematika, ada pula faktor lain yaitu jenis kelamin yang digolongkan menjadi dua, yaitu laki-laki dan perempuan. Hasil penelitian Tanjung (2018) menyebutkan saat menerima informasi dan menyimpan informasi, ditemukan perbedaan proses berpikir antara siswa laki-laki dan perempuan. Adapun penelitian yang dilakukan oleh Purwanto et al., (2019) yang menyatakan adanya perbedaan strategi yang digunakan siswa laki-laki dan perempuan saat menyelesaikan masalah. Beberapa penelitian mengungkapkan bahwa perbedaan jenis kelamin berpengaruh terhadap pencapaian matematika yang akan semakin terlihat saat siswa menempuh jenjang yang lebih tinggi (Ganley \& Vasilyeva, 2011). Perbedaan tersebut mungkin juga akan memunculkan perbedaan proses berpikir siswa dalam memecahkan masalah matematika kontekstual.

Berdasarkan berbagai permasalahan, informasi, dan hasil observasi di atas, mengetahui proses berpikir siswa dalam memecahkan masalah matematika kontekstual ditinjau dari kemamapuan matematika dan jenis kelamin dapat membantu guru matematika untuk mengetahui perbedaan karakteristik siswa dalam memecahkan masalah dan memperbaiki kesalahan pengetahuan yang dialami siswa, juga untuk menentukan metode pembelajaran yang tepat, sehingga siswa mampu meningkatkan kemampuan berpikir dalam memecahkan masalah matematika. Oleh sebab itu, peneliti melakukan penelitian dengan tujuan untuk mengetahui dan memperoleh deskripsi proses berpikir siswa dalam memecahkan masalah matematika kontekstual ditinjau dari kemampuan matematika dan jenis kelamin.

\section{METODE}

Berdasarkan tujuannya penelitian ini merupakan penelitian deskriptif menggunakan pendekatan kualitatif dan memiliki tujuan untuk mendeskripsikan proses berpikir siswa dalam memecahkan masalah matematika kontekstual ditinjau dari kemampuan matematika dan jenis kelamin. Instrumen utama penelitian ini adalah peneliti, dan instrumen pendukung adalah tes kemampuan Matematika (TKM), tugas pemecahan masalah matematika kontekstual (TPMMK), dan pedoman wawancara yang telah divalidasi oleh validator ahli dan kompeten, hasil validasi yang menunjukkan saran dan masukan dari validator digunakan sebagai bahan revisi. Sumber data penelitian ini yaitu siswa SMP Negeri 2 Kota Mojokerto kelas VIII sebanyak 50 siswa yang telah memperoleh materi SPLDV. Siswa diberikan soal TKM, terdiri dari 10 soal untuk mengelompokkan siswa berdasarkan tiga kategori tingkat kemampuan matematika yaitu kategori tinggi ketika skor yang diperoleh $80 \leq$ skor $\leq 100$, kategori sedang ketika skor yang diperoleh $60 \leq$ skor $<80$, dan kategori rendah ketika skor yang diperoleh $0 \leq$ skor $<60$. Subjek yang dipilih adalah 6 siswa, yang terdiri dari siswa laki-laki dan perempuan dimana masing-masing jenis kelamin, terdiri dari siswa berkemampuan matematika tinggi, sedang, dan rendah. Selanjutnya, memberikan TPMMK pada materi sistem persamaan linear dua variabel (SPLDV). Proses selanjutnya, 6 subjek penelitian akan diwawancarai, dengan tujuan untuk melengkapi data yang tidak diperoleh dari hasil TPMMK. Proses berpikir siswa dalam penelitian ini dianalisis menggunakan indikator proses berpikir siswa dalam memecahkan masalah matematika berdasarkan langkah Polya dan teori pemrosesan informasi menurut Slavin yang diadaptasi dari penelitian Fauziyah (2020) sebagai berikut. 
Tabel 2. 1 Indikator Proses Berpikir Siswa dalam Memecahkan Masalah

\begin{tabular}{|c|c|c|c|}
\hline $\begin{array}{l}\text { Tahap } \\
\text { Pemecahan } \\
\text { Masalah }\end{array}$ & $\begin{array}{l}\text { Proses } \\
\text { Berpikir }\end{array}$ & Indikator & Kode \\
\hline \multirow{4}{*}{$\begin{array}{l}\text { Memahami } \\
\text { masalah }\end{array}$} & $\begin{array}{l}\text { Menerima } \\
\text { informasi }\end{array}$ & $\begin{array}{l}\text { Mengakses informasi (melalui indera) dalam memahami masalah } \\
\text { kontekstual } \\
\text { Membaca masalah yang diberikan, memahami masalah yang diberikan }\end{array}$ & A1 \\
\hline & $\begin{array}{l}\text { Menyimpan } \\
\text { informasi }\end{array}$ & $\begin{array}{l}\text { Melakukan pengulangan dalam membaca masalah kontekstual yang } \\
\text { diberikan }\end{array}$ & A2 \\
\hline & $\begin{array}{l}\text { Mengolah } \\
\text { informasi }\end{array}$ & $\begin{array}{l}\text { Menyebutkan tujuan serta mengidentifikasi kecukupan data untuk } \\
\text { memecahkan masalah kontekstual }\end{array}$ & A3 \\
\hline & $\begin{array}{l}\text { Memanggil } \\
\text { kembali } \\
\text { informasi }\end{array}$ & $\begin{array}{l}\text { Mendeskripsikan kembali permasalahan dengan bahasa sendiri } \\
\text { Mengingat kembali cara pemahaman masalah kontekstual yang telah } \\
\text { dilakukan sebelumnya } \\
\text { Mengaitkan pengetahuan terdahulu dengan informasi pada soal. }\end{array}$ & A4 \\
\hline \multirow[b]{2}{*}{$\begin{array}{l}\text { Merencanakan } \\
\text { penyelesaian }\end{array}$} & $\begin{array}{l}\text { Memanggil } \\
\text { kembali }\end{array}$ & $\begin{array}{l}\text { Mengingat konsep, rumus, aturan, aturan serupa atau pengetahuan lain yang } \\
\text { sudah dikuasai untuk menyusun rencana penyelesaian }\end{array}$ & B1 \\
\hline & $\begin{array}{l}\text { Mengolah } \\
\text { informasi }\end{array}$ & $\begin{array}{l}\text { Menjelaskan ide atau langkah yang digunakan untuk memecahkan masalah, } \\
\text { Mengaitkan informasi yang ada di soal dengan pengetahuan yang dimiliki } \\
\text { sebelumnya }\end{array}$ & B2 \\
\hline \multirow{2}{*}{$\begin{array}{l}\text { Melaksankan } \\
\text { rencana } \\
\text { penyelesaian }\end{array}$} & $\begin{array}{l}\text { Memanggil } \\
\text { kembali } \\
\text { informasi }\end{array}$ & $\begin{array}{l}\text { Mengingat informasi yang penting } \\
\text { Menggunakan rencana penyelesaian sebelumnya untuk menyelesaikan } \\
\text { masalah }\end{array}$ & $\mathrm{C} 1$ \\
\hline & $\begin{array}{l}\text { Mengolah } \\
\text { informasi }\end{array}$ & $\begin{array}{l}\text { Mengaitkan penyelaian dari soal dengan pengetahuan yang dikuasai } \\
\text { Berargumen logis dalam melaksanakan penyelesaian } \\
\text { Memilih dan menerapkan strategi untuk menyelesaikan model atau masalah } \\
\text { matematika dan atau di luar matematika }\end{array}$ & $\mathrm{C} 2$ \\
\hline \multirow[b]{2}{*}{$\begin{array}{l}\text { Memeriksa } \\
\text { kembali }\end{array}$} & $\begin{array}{l}\text { Memanggil } \\
\text { kembali }\end{array}$ & $\begin{array}{l}\text { Mengingat penyelesaian yang dilakukan, inti permasalahan atau } \\
\text { pengetahuan yang dikuasai }\end{array}$ & D1 \\
\hline & $\begin{array}{l}\text { Mengolah } \\
\text { informasi }\end{array}$ & $\begin{array}{l}\text { Mengetahui adanya gagasan yang salah } \\
\text { Memeriksa kebenaran hasil atau jawaban } \\
\text { Mengetahui hal penting yang perlu diperiksa dalam pemecahan masalah }\end{array}$ & D2 \\
\hline
\end{tabular}

Setelah mengerjakan soal TPMMK, keenam siswa diwawancarai secara bergantian. Pertanyaan yang diajukan oleh peneliti terkait hasil pengerjaan TPMMK. Peneliti mencocokan antara pengerjaan TPMMK oleh siswa dengan hasil wawancara. Kemudian melakukan analisis menggunakan indikator Tabel 2.1. Peneliti menyusun deskripsi proses berpikir siswa dalam memecahkan masalah matematika kontektual ditinjau dari kemampuan matematika dan jenis kelamin. Penelitian ini menggunakan analisis data deskriptif dengan pendekatan kualitatif model Milles dan Hubberman. Model tersebut terdiri dari reduksi data, penyajian data, verifikasi (pemeriksaan kebenaran) dan pengambilan keputusan (Moleong, 2012).

\section{HASIL DAN PEMBAHASAN}

Berdasarkan TKM terhadap 50 siswa SMP kelas VIII, diperoleh 3 siswa laki-laki dan 13 siswa perempuan berkemampuan matematika tinggi, 8 siswa laki-laki dan 7 siswa perempuan berkemampuan matematika sedang, 10 siswa laki-laki dan 9 siswa perempuan berkemampuan matematika rendah. Kemudian, siswa dengan kemampuan komunikasi yang baik secara verbal maupun tertulis berdasarkan pertimbangan dari guru matematika dijadikan sebagai subjek pada penelitian ini. Subjek penelitian yang terpilih yaitu sebagai berikut.

Tabel 3. 1 Subjek Penelitian

\begin{tabular}{|c|l|c|c|l|}
\hline No. & Nama & L/P & Nilai & Kategori \\
\hline 1. & SLT & L & 90 & Tinggi \\
\hline 2. & SPT & P & 100 & Tinggi \\
\hline 3. & SLS & L & 75 & Sedang \\
\hline 4. & SPS & P & 70 & Sedang \\
\hline
\end{tabular}




\begin{tabular}{|c|l|c|c|l|}
\hline 5. & SLR & L & 55 & Rendah \\
\hline 6. & SPR & P & 50 & Rendah \\
\hline
\end{tabular}

Proses berpikir siswa laki-laki berkemampuan matematika tinggi (SLT)

1. Memahami Masalah

SLT dapat menerima informasi dengan membaca menggunakan indera dan memahami masalah yang disajikan. Sesuai pendapat (Ngilawajan, 2013) bahwa siswa akan lebih mudah untuk memahami dan mengingat ketika memberikan perhatian lebih pada informasi dengan cara membaca soal secara teliti.

SLT dapat menyimpan informasi dengan membaca dua kali. Pernyataan yang mendukung yaitu ketika pengetahuan sesorang semakin banyak, maka semakin mudah pula seseorang dalam mengorganisasi informasi baru. SLT mengalami sedikit kesulitan karena hanya memerlukan dua kali kesempatan untuk memahami soal (Woolfolk 1995).

SLT dapat mengolah informasi dengan menyebutkan tujuan dan mengidentifikasi kecukupan data secara lisan dengan tepat, menguraikan apa saja yang diketahui yaitu harga pensil, penghapus, penggaris, dan sampul plastik, lalu perlu dicari harga barang dari slip pembayaran, dan yang ditanyakan pada soal yaitu Ani hanya memiliki uang $R p 6.000$, dan Ani berpikir apakah uang tersebut cukup untuk membeli sebuah pensil dan sebuah penggaris.

SLT dapat memanggil kembali informasi dengan menjelaskan maksud soal menggunakan bahasa sendiri, SLT pernah mendapatkan soal serupa sehingga dapat menggunakan serta menghubungkan pengetahuan yang dimiliki sebelumnya. Uraian tersebut menjelaskan bahwa siswa menafsirkan informasi (persepsi) dengan mengetahui hubungan antara pengetahuan terdahulu dan informasi yang diterima. Sesuai pendapat Slavin (2008) bahwa keadaan pikiran yang berasal dari pengalaman masa lampau, pengetahuan, dorongan dari dalam diri sendiri atau motivasi, serta faktor lainnya mempengaruhi persepsi siswa dan melibatkan penafsiran pikiran.

\section{Merencanakan Penyelesaian}

SLT dapat memanggil kembali pengetahuan terdahulu dengan menyebutkan konsep, rumus, serta aturan yang digunakan untuk memecahkan masalah, yaitu SPLDV, operasi bentuk aljabar, serta menyusun suatu persamaan berdasarkan masalah kontekstual.

Tabel 3. 2 Wawancara SLT tahap merencanakan penyelesaian

\begin{tabular}{|c|l|}
\hline Kode & \multicolumn{2}{|c|}{ Kegiatan } \\
\hline PSLT $_{1}$ & $\begin{array}{l}\text { Jelaskan bagaimana kamu menggunakan } \\
\text { konsep yang sudah kamu sebutkan } \\
\text { sebelumnya untuk menyelesaikan masalah? }\end{array}$ \\
\hline JSLT $_{1}$ & $\begin{array}{l}\text { Saya menggunakan SPLDV mbak untuk } \\
\text { mengerjakan, itu kan untuk mengetahui harga }\end{array}$ \\
\hline
\end{tabular}

\begin{tabular}{|l|l|}
\hline tiap barang dari slip 1, dan slip 2 mbak jadi \\
saya mencari persamaan 1 dan 2, persamaan 1 \\
dari slip 1 persamaan 2 dari slip 2, terus dicari \\
$x$ sama y nya.
\end{tabular}

$$
\left.\begin{array}{ll}
\operatorname{Sin} I & 2 x+5 y=18500 \\
\operatorname{Sip} I & x+2 y=8000
\end{array}\right\} \quad \operatorname{JSLT}_{1}
$$

\section{Gambar 3. 1 Lembar jawaban SLT pada TPMMK}

Berdasarkan petikan wawancara tabel 3.2, SLT dapat mengolah informasi dengan menjelaskan ide atau langkah yang akan digunakan untuk memecahkan masalah dengan mengaitkan pengetahuan yang dimiliki sebelumnya yaitu menyusun persamaan melalui kedua slip yang disajikan, penjelasan SLT lebih lengkap secara lisan, dilihat dari gambar 3.1, SLT membuat pemisalan untuk penggaris, dan pensil, kemudian menentukan harga untuk 2 penggaris dan 5 pensil dengan melihat informasi pada slip 1, dan mencari harga untuk 2 pensil dan 1 penggaris melihat informasi pada slip 2.

3. Melaksanakan Rencana Penyelesaian

Tabel 3. 3 Wawancara SLT Tahap melaksanakan rencana

\begin{tabular}{|c|l|}
\hline Kode & \multicolumn{1}{|c|}{ Kegiatan } \\
\hline PSLT $_{2}$ & $\begin{array}{l}\text { Apakah kamu menggunakan idemu } \\
\text { sebelumnya untuk menyelesaikan soal? }\end{array}$ \\
\hline JSLT $_{2}$ & $\begin{array}{l}\text { Iya mbak saya pakai SPLDV dan persamaan } \\
\text { yang sudah saya buat tadi. }\end{array}$ \\
\hline PSLT $_{3}$ & $\begin{array}{l}\text { Ceritakan langkah penyelesaian yang telah } \\
\text { kamu kerjakan? }\end{array}$ \\
\hline JSLT $_{3}$ & $\begin{array}{l}\text { Persamaan tadi yang sudah saya cari dari slip } \\
\text { 1 dan 2 saya eliminasi, dikalikan 1 untuk } \\
\text { persamaan 1 dikalikan 2 untuk persamaan dua } \\
\text { terus saya gunakan metode eliminasi, ketemu } \\
\text { mencari harga sebuah penggarisnya saya } \\
\text { gunakan subtitusi. y tadi ketemu 2.500 saya } \\
\text { subtitusi ke persamaan dua ketemu hasilnya } \\
\text { 3.000 harga satu penggaris. }\end{array}$ \\
\hline
\end{tabular}

Berdasarkan tabel 3.3, SLT dapat memanggil kembali informasi dengan mengingat kembali informasi penting yang disebutkan sebelumnya dan menggunakan ide yang telah direncanakan untuk menyelesaikan masalah dengan tepat sehingga menghasilkan jawaban benar (JSLT 2 ), sesuai dengan hasil penelitian Isroil et al., (2017) subjek berkemampuan matematika tinggi mampu menggunakan

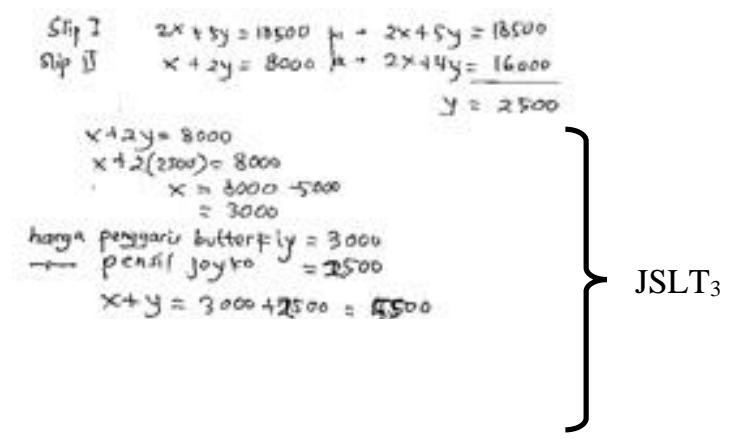


pengetahuan terdahulu untuk melaksanakan penyelesaian guna memperoleh hasil yang benar.

Gambar 3. 2 Lembar jawaban SLT pada TPMMK

Petikan wawancara pada tabel 3.3 memperlihatkan SLT dapat mengolah informasi dengan menjelaskan cara yang dilakukan untuk memecahkan masalah, mengaitkan rencana penyelesaian dari soal dengan pengetahuan terdahulu, yaitu operasi hitung bilangan, operasi bentuk aljabar, menentukan persamaan melalui masalah, dan menyajikan masalah kontekstual kedalam bentuk model matematika, yaitu SPLDV untuk menyelesaikan masalah dengan tepat, mampu memberikan argumen logis dalam rencana penyelesaian yang telah disusun serta dapat memilih dan menerapkan strategi untuk model dengan tepat, berdasarkan gambar 3.2, metode yang digunakan adalah eliminasi dan subtitusi. Sesuai hasil penelitian Trifatmasari \& Kurniasari (2016) bahwa subjek dengan kemampuan matematika tinggi saat merencanakan penyelesaian mampu mengingat kembali, mempertimbangkan, membuat argumen, dan memutuskan dimana proses berpikir tersebut dilakukan secara maksimal.

4. Memeriksa Kembali

Tabel 3. 4 Wawancara SLT tahap memeriksa kembali

\begin{tabular}{|c|l|}
\hline Kode & \multicolumn{1}{|c|}{ Kegiatan } \\
\hline PSLT $_{4}$ & $\begin{array}{l}\text { Apakah kamu memeriksa kembali } \\
\text { jawabanmu setelah mendapatkannya? }\end{array}$ \\
\hline JSLT $^{4}$ & Iya dicek mbak \\
\hline PSLT $_{5}$ & Bagaimana caramu memeriksanya? \\
\hline JSLT $_{5}$ & $\begin{array}{l}\text { Dicek semuanya dari awal mulai dari } \\
\text { membuat persamaan sampai hasil akhirnya. }\end{array}$ \\
\hline
\end{tabular}

$$
\begin{aligned}
& \text { harga pengari butterfly }=3000 \\
& \text { pensil joyko }=2500 \\
& x+y=3000+2500=5500 \\
& 4 \text { ang Ani culup untuk membeb } \\
& \text { penggaris den pensil yang sama, merbinga. }
\end{aligned}
$$

Gambar 3. 3 Lembar jawaban SLT pada TPMMK

SLT dapat memanggil kembali informasi dengan membuat kesimpulan bahwa hasil yang didapat sudah menjawab pertanyaan baik secara lisan maupun tulisan sesuai gambar 3.3.

Berdasarkan tabel 3.4, SLT dapat mengolah informasi dengan memeriksa seluruh langkah dari awal hingga jawaban akhirnya dan mampu menemukan gagasan yang salah. Hal ini sesuai dengan hasil penelitian Listanti et al., (2020) bahwa siswa berkemampuan matematika tinggi mampu mengecek informasi dan semua perhitungan yang

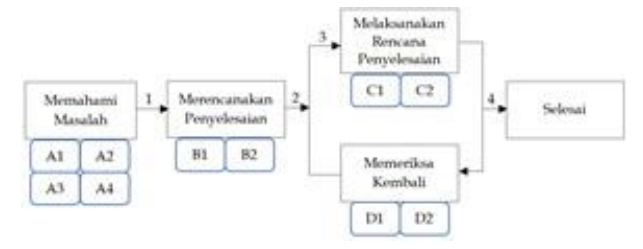

terlibat dalam penyelesaian soal. Berdasarkan hasil analisis dan pembahasan, diperoleh skema proses berpikir sebagai berikut;

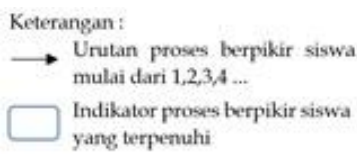

Gambar 3. 4 Skema Proses Berpikir SLT

Skema proses berpikir SLT pada gambar 3.4, menjelaskan bahwa SLT melakukan semua tahapan proses berpikir siswa dalam memecahkan masalah dan memenuhi semua indikator pada tabel 2.1, SLT mengulangi tahap melaksanakan rencana penyelesaian dan memeriksa kembali sebelum akhirnya memperoleh penyelesaian seperti yang terdapat pada tabel 3.4 tahap memeriksa kembali.

\section{Proses berpikir siswa perempuan berkemampuan matematika tinggi (SPT)}

\section{Memahami Masalah}

SPT dapat menerima informasi dengan membaca masalah yang disajikan menggunakan indera dan memahami maksud soal. Sesuai dengan pendapat Robert (1995) bahwa siswa memberikan perhatian terhadap soal atau menyadari informasi yang ada disektarnya sehingga informasi tersebut akan diterima oleh panca indera.

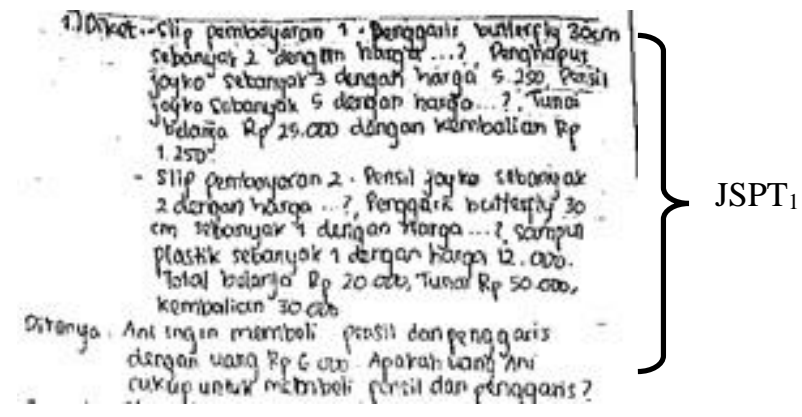

Gambar 3. 5 Lembar jawaban SPT pada TPMMK

SPT dapat menyimpan informasi dengan membaca dua sampai tiga kali. Sehingga memperlihatkan bahwa SPT memiliki sedikit kesulitan saat memahami soal, pernyataan yang mendukung yaitu ketika pengetahuan sesorang semakin banyak, maka semakin mudah pula seseorang dalam mengorganisasi informasi baru (Woolfolk 1995). SPT lebih banyak melakukan pengulangan dari pada SLT, pendapat ini didukung oleh hasil penelitian Purwanto et al., (2019) yang mengungkapkan bahwa diantara siswa laki-laki dan perempuan, siswa perempuan lebih banyak mengumpulkan fakta dengan membaca kembali soal serta mencermati masalah dengan seksama.

Berdasarkan gambar 3.5, SPT dapat mengolah informasi dengan menyebutkan tujuan dan mengidentifikasi kecukupan data dengan cara 
memaparkan hal yang ditanyakan dan diketahui pada soal dengan mendetail secara lisan maupun tulisan (JSPT 1 ). Hal ini ditunjang oleh pendapat Kartono \& Kartini (1989) perempuan pada umumnya lebih akurat dan mendetail dari pada laki-laki dalam membuat catatan namun seringkali catatan tersebut kurang kritis hal ini disebabkan karena perempuan kurang mampu membedakan bagian penting dan bagian yang kurang pokok.

SPT dapat memanggil kembali informasi dengan menjelaskan maksud soal menggunakan bahasa sendiri, SPT pernah mendapatkan soal serupa sehingga dapat menggunakan serta menghubungkan pengetahuan yang dimiliki sebelumnya. Uraian tersebut menjelaskan bahwa siswa menafsirkan informasi (persepsi) dengan mengetahui hubungan antara pengetahuan terdahulu dan informasi yang diterima. Sesuai pendapat Slavin (2008) bahwa keadaan pikiran yang berasal dari pengalaman masa lampau, pengetahuan, dorongan dari dalam diri sendiri atau motivasi, serta faktor lainnya mempengaruhi persepsi siswa dan melibatkan penafsiran pikiran.

\section{Merencanakan Penyelesaian}

SPT dapat memanggil kembali informasi dan memecahkan masalah secara tepat, karena mampu menyebutkan konsep, rumus, serta aturan yang digunakan. Konsep dan aturan yang disebutkan adalah SPLDV, operasi bentuk aljabar, menyusun suatu persamaan pada masalah kontekstual yang disajiakan.

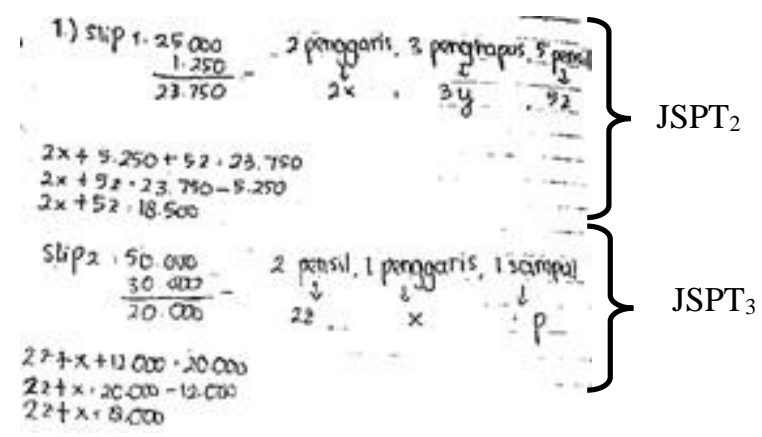

Gambar 3. 6 Lembar jawaban SPT pada TPMMK

Berdasarkan gambar 3.6, SPT dapat mengolah informasi dengan menjelaskan ide atau langkah yang akan digunakan untuk memecahkan masalah dengan mengaitkan pengetahuan yang dimiliki sebelumnya yaitu menyusun persamaan melalui kedua slip yang disajikan $\left(\mathrm{JSPT}_{2}\right.$ dan $\left.\mathrm{JSPT}_{3}\right)$, SPT membuat pemisalan untuk penggaris, penghapus, pensil, dan sampul plastik, kemudian menentukan harga untuk 2 penggaris dan 5 pensil dengan melihat informasi pada slip 1, kemudian mencari harga untuk 2 pensil dan 1 penggaris dengan melihat informasi pada slip 2.

3. Melaksanakan Rencana Penyelesaian

SPT dapat memanggil kembali informasi dengan mengingat informasi penting yang disebutkan sebelumnya dan menggunakan ide yang telah direncanakan untuk menyelesaikan masalah dengan tepat sehingga menghasilkan jawaban benar, sesuai dengan hasil penelitian Isroil et al., (2017) subjek berkemampuan matematika tinggi mampu menggunakan pengetahuan terdahulu untuk melaksanakan penyelesaian guna memperoleh hasil yang benar.

Tabel 3. 5 Wawancara SPT Tahap melaksanakan rencana

\begin{tabular}{|c|l|}
\hline Kode & \multicolumn{1}{|c|}{ Kegiatan } \\
\hline PSPT $_{4}$ & $\begin{array}{l}\text { Ceritakan langkah penyelesaian yang telah } \\
\text { kamu kerjakan? }\end{array}$ \\
\hline & $\begin{array}{l}\text { Sebenarnya awalnya sebelum mau } \\
\text { menggunakan persamaan itu saya pakai } \\
\text { pecahan mbak, tapi kok bingung akhirnya } \\
\text { saya cek lagi soalnya baru ketemu persamaan. } \\
\text { JSPT }_{4}\end{array}$ \\
$\begin{array}{l}\text { Jadi, kan tadi udah ketemu dua persamaan } \\
\text { terus saya pakai SPLDV mbak, pertamanya } \\
\text { saya nyari x sama z nya itu, saya cari z nya } \\
\text { dulu, itu saya kalikan 1 sama saya kalikan 2 } \\
\text { terus ketemu z, yang kedua saya kalikan 2 } \\
\text { sama 5 terus ketemu x, terus setelah ketemu z } \\
\text { sama x saya jumlahkan kan ketemu 5.500. }\end{array}$ \\
\hline
\end{tabular}

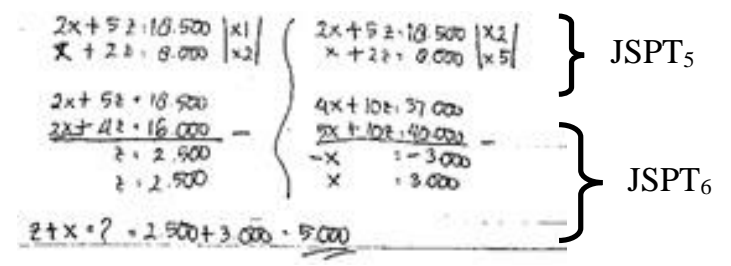

Gambar 3. 7 Lembar jawaban SPT pada TPMMK

Berdasarkan gambar 3.7, SPT dapat mengolah informasi dengan mengaitkan rencana penyelesaian dari soal dengan pengetahuan terdahulu secara tepat (JSPT 5 dan JSPT $_{6}$ ). Berdasarkan tabel 3.5, SPT mengalami kesalahan saat merencakan masalah dan mencoba memahami kembali maksud soal (JSPT 4 ). SPT mampu memberikan argumen logis serta dapat memilih dan menerapkan strategi dengan tepat, metode yang digunakan adalah eliminasi. Sesuai hasil penelitian Trifatmasari \& Kurniasari (2016) bahwa subjek dengan kemampuan matematika tinggi saat merencanakan penyelesaian mampu mengingat kembali, mempertimbangkan, membuat argumen, dan memutuskan dimana proses berpikir tersebut dilakukan secara maksimal.

4. Memeriksa Kembali

Tabel 3. 6 Wawancara SPT tahap memeriksa kembali

\begin{tabular}{|c|c|}
\hline Kode & Kegiatan \\
\hline $\mathrm{PSPT}_{7}$ & Coba jelaskan dek, kesimpulan kamu \\
\hline $\mathrm{JSPT}_{7}$ & $\begin{array}{l}\text { Pertanyaanya kan tadi Ani membawa uang } \\
6.000 \text { apakah uang itu cukup untuk membeli } \\
\text { lagi sebuah penggaris dan sebuah pensil? } \\
\text { Ternyata uang Ani cukup mbak, totalnya } \\
5.500 \text { jadi kembalinya } 500\end{array}$ \\
\hline
\end{tabular}




\begin{tabular}{|l|l|}
\hline PSPT $_{8}$ & Disini hasilnya 5.000 \\
\hline $\mathrm{JSPT}_{8}$ & $\begin{array}{l}\text { Oiyaa kak salah tulis, seharusnya total } \\
\text { harganya 5.500 }\end{array}$ \\
\hline
\end{tabular}

$$
z+x \cdot ?=2.500+3000 \cdot 5.000\} \mathrm{JSPT}_{8}
$$

Gambar 3. 8 Lembar jawaban SPT pada TPMMK

SPT dapat memanggil kembali informasi dengan membuat kesimpulan dan mengungkapkan hasil yang didapatkan sudah menjawab pertanyaan secara lisan sesuai petikan wawancara pada tabel $3.6\left(\mathrm{JSPT}_{7}\right)$.

SPT dapat mengolah informasi dengan memeriksa seluruh hasil pengerjaannya dari awal hingga jawaban akhir, SPT juga memeriksa kembali saat merencanakan rencana penyelesaian ketika menyadari bahwa ada kesalahan langkah yang akan digunakan. Berdasarkan gambar 3.8, SPT mengungkapkan mengalami kesalahan penulisan dan menyadarinya (JSPT 8 ). Hal ini ditunjang dengan pendapat Listanti et al., (2020) siswa menggabungkan pengetahuannya dalam memecahkan masalah untuk melihat solusi yang telah dikerjakan, mempertimbangkan kembali hasil dan cara yang mengarah ke penyelesaian. Berdasarkan hasil analisis dan pembahasan, diperoleh skema proses berpikir sebagai berikut;

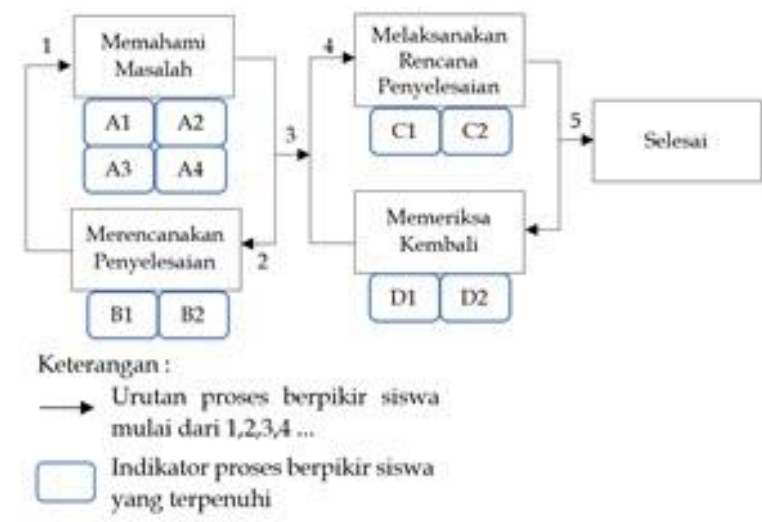

Gambar 3. 9 Skema Proses Berpikir SPT

Skema proses berpikir SPT pada gambar 3.9, menjelaskan bahwa SPT melakukan semua tahapan proses berpikir siswa dalam memecahkan masalah dan memenuhi semua indikator pada tabel 2.1, SPT mengulangi tahap memahami masalah dan merencanakan penyelesaian sebelum menuju tahap berikutnya, hal ini sesuai dengan petikan wawancara SPT pada tabel 3.5, yang menjelaskan bahwa SPT mengalami gangguan saat membuat rencana penyelesaian yang pertama kemudian mencoba memahami soal kembali. SPT juga mengulangi tahap melaksanakan rencana penyelesaian dan memeriksa kembali sebelum akhirnya memperoleh penyelesaian.

\section{Proses berpikir siswa laki-laki berkemampuan matematika sedang (SLS)}

\section{Memahami Masalah}

SLS dapat menerima informasi, SLS membaca masalah yang disajikan menggunakan indra namun kurang memahami maksud soal, sesuai pendapat Robert (1995) bahwa siswa memberikan perhatian terhadap soal atau menyadari informasi yang ada disektarnya sehingga informasi tersebut akan diterima oleh panca indera.

SLS dapat menyimpan informasi dengan membaca soal lebih dari tiga kali kesempatan, sehingga memperlihatkan bahwa SLS memiliki kesulitan saat memahami soal, yang dapat disebabkan oleh pengalaman atau pengetahuan SLS masih kurang, pernyataan yang mendukung yaitu ketika pengetahuan sesorang semakin banyak, maka semakin mudah pula seseorang dalam mengorganisasi informasi baru (Woolfolk 1995).

SLS dapat mengolah informasi dengan menyebutkan tujuan dan mengidentifikasi kecukupan data, menguraikan apa saja yang diketahui secara lisan yaitu terdapat dua slip dan keterangan harga, serta ada harga barang yang tidak diketahui, dan uang Ani hanya Rp6.000 untuk membeli barang yang dibutuhkan, mengungkapkan tujuan yang dimaksud soal yaitu menentukan apakah uang Ani cukup untuk membeli pensil dan penggaris.

SLS kurang mampu memanggil kembali informasi karena saat mengungkapkan maksud soal dengan bahasa sendiri SLS hanya menguraikan apa yang ditanyakan. Selain itu SLS tidak dapat menghubungkan pengetahuan yang dimilki untuk menyelesaikan masalah, karena SLS mengalami gangguan di dalam pikirannya, SLS mengalami kegagalan saat memanggil kembali informasi yang dimiliki. Sesuai penelitian Putra (2017) yang menjelaskan bahwa siswa tidak mampu memanggil kembali informasi yang dimiliki karena terjadinya fragmented atau tidak saling terhubungnya konsep yang tersimpan di long term memory.

2. Merencanakan Penyelesaian

SLS dapat memanggil kembali informasi dengan menyebutkan konsep, rumus, serta aturan yang digunakan untuk memecahkan masalah yaitu, soal cerita, SPLDV, dan operasi bentuk aljabar.

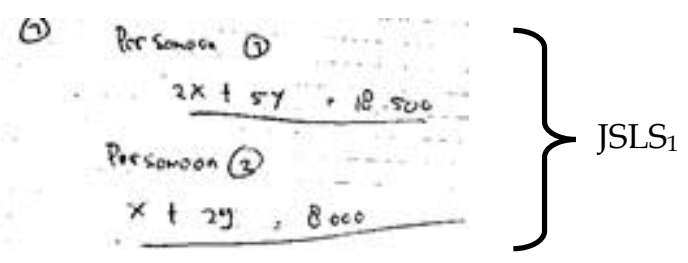

Gambar 3. 10 Lembar jawaban SLS pada TPMMK

Berdasarkan gambar 3.10, SLS dapat mengolah informasi dengan menjelaskan ide atau langkah yang akan digunakan untuk memecahkan masalah dengan 
mengaitkan pengetahuan yang dimiliki sebelumnya yaitu menyusun persamaan melalui kedua slip yang disajikan (JSLS 1$)$, SLS membuat pemisalan untuk penggaris dan pensil, menentukan harga untuk 2 penggaris dan 5 pensil dengan melihat informasi pada slip 1 , kemudian mencari harga untuk 2 pensil dan 1 penggaris dengan melihat informasi pada slip 2.

3. Melaksanakan Rencana Penyelesaian

SLS dapat memanggil kembali informasi dengan menjelaskan informasi penting dan ide yang telah direncanakan sebelumnya, namun penjelasan yang diberikan kurang benar yang menyebabkan jawaban siswa cenderung salah, hal ini menunjukkan bahwa terdapat gangguan atau halangan di dalam pikiran siswa saat memecahkan masalah. Berdasarkan hal tersebut Slavin (2008) mengungkapkan bahwa saat informasi yang dimiliki tercampur atau tersingkirkan oleh informasi lain, saat itulah terjadi sebuah gangguan.

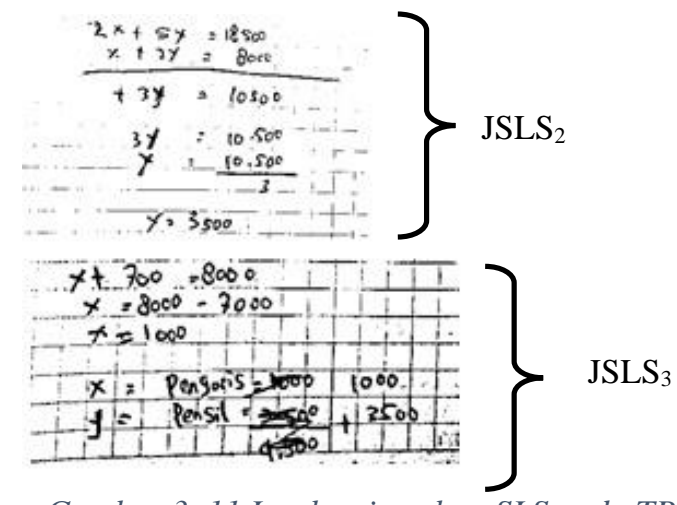

Gambar 3. 11 Lembar jawaban SLS pada TPMMK

Berdasarkan gambar 3.11, SLS kurang mampu mengolah informasi, SLS tidak dapat mengaitkan rencana penyelesaian dari soal dengan pengetahuan terdahulu secara tepat. SLS menjelaskan cara yang dilakukan untuk memecahkan masalah, yaitu dengan mengurangi kedua persamaan yang telah disusun (JSLS 2$)$. SLS mengalami kesalahan dalam melakukan eliminasi untuk mencari nilai $y \quad\left(\mathrm{JSLS}_{2}\right.$ dan $\left.\mathrm{JSLS}_{3}\right)$ Selain itu, SLS tidak mampu memberikan argumen logis dan tidak dapat mengungkap strategi metode yang digunakan beserta alasannya. SLS sempat mengalami kesulitan untuk menentukan metode yang digunakan, kemudian kembali lagi ke langkah merencanakan penyelesaian untuk menentukan langkah selanjutnya. Hal tersebut ditunjang oleh pendapat Kusaeri et al., (2018) bahwa siswa tidak melakukan pemanggilan kembali dengan tepat sehingga solusi tidak relevan dan respon yang didapatkan salah. Respon siswa yang salah dikarenakan konsep-konsep yang dibutuhkan tidak terekam oleh memori siswa.

4. Memeriksa Kembali

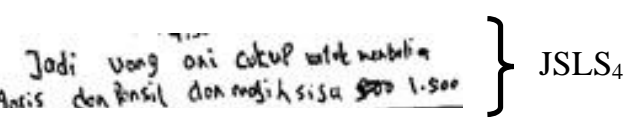

Gambar 3. 12 Lembar jawaban SLS pada TPMMK
Berdasarkan gambar 3.12, SLS kurang mampu memanggil kembali informasi, karena kesimpulan yang diperoleh kurang tepat akibat dari kesalahan pada tahap sebelumnya

SLS kurang mampu mengolah informasi, SLS tidak memeriksa kembali langkah penyelesaian, tidak menyadari adanya gagasan yang salah dalam penyelesaian yang dibuat, hal ini dikarenakan SLS kurang teliti pernyataan tersebut didukung oleh hasil penelitian Nurhayati et al., (2020) karena kesalahan saat memanggil kembali informasi yang sudah disimpan sehingga siswa berkemampuan matematika sedang telah menyimpan kesalahan konsep. Berdasarkan hasil analisis dan pembahasan, diperoleh skema proses berpikir sebagai berikut;

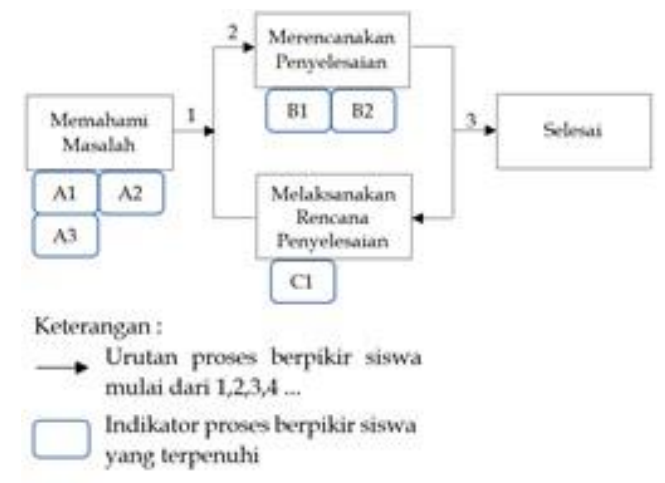

Gambar 3. 13 Skema Proses Berpikir SLS

Skema proses berpikir SLS pada gambar 3.13, menjelaskan bahwa SLS tidak melakukan tahap memeriksa kembali, dan ada beberapa indikator pada tabel 2.1 yang tidak terpenuhi atau tidak dilakukan oleh siswa. SLS mengulangi tahap merencanakan penyelesaian dan melaksanakan rencana penyelesaian sebelum akhirnya memperoleh penyelesaian.

\section{Proses berpikir siswa perempuan berkemampuan matematika sedang (SPS)}

\section{Memahami Masalah}

SPS dapat menerima informasi dengan membaca masalah yang disajikan menggunakan indra namun tidak sepenuhnya memahami maksud soal. Robert (1995) bahwa siswa memberikan perhatian terhadap soal atau menyadari informasi yang ada disekitarnya sehingga informasi tersebut akan diterima oleh panca indera.

SPS dapat menyimpan informasi dengan membaca lebih dari lima kali soal yang diberikan. Pernyataan tersebut memperlihatkan bahwa SPS mendapati kesulitan saat memahami soal dan memerlukan lebih banyak kesempatan untuk memahami, hal ini dapat disebabkan karena pengalaman atau pengetahuan yang dimiliki SPS tentang materi pada soal masih kurang hal ini ditunjang penelitian Nurhayati et al., (2020) yang menyebutkan 
pengalaman dari individu, mempengaruhi kemampuan individu dalam mengidentifikasi masalah.

Tabel 3. 7 Wawancara SPS Tahap memahami masalah

\begin{tabular}{|c|l|}
\hline Kode & \multicolumn{1}{|c|}{ Kegiatan } \\
\hline PSPS $_{1}$ & $\begin{array}{l}\text { Informasi apakah yang kamu peroleh dari } \\
\text { soal? }\end{array}$ \\
\hline JSPS $_{1}$ & $\begin{array}{l}\text { Yang pengaris butterflynya kan 2 pensil } \\
\text { joykonya 5 yang slip 1 terus penghapusnya 3 } \\
\text { terus tunainya itu 25.000 terus kembaliannya } \\
\text { 1.250 } \\
\text { Kalau slip 2 itu pensil joykonya 2, penggaris } \\
\text { butterflynya 1, sampul plastiknya 1, total } \\
\text { harganya Rp20.000, tunainya Rp50.000 } \\
\text { kembaliannya Rp30.000, uang Ani Rp6.000 }\end{array}$ \\
\hline
\end{tabular}

SPS dapat mengolah informasi dengan menyebutkan tujuan dan mengidentifikasi kecukupan data, sesuai petikan wawancara pada tabel 3.7, SPS menguraikan apa saja yang diketahui (JSPS 1 ) dan yang ditanyakan pada soal dengan mendetail secara lisan yaitu menentukan apakah uang Ani cukup untuk membeli pensil dan penggaris hal tersebut didukung oleh hasil penelitian Nurhayati et al., (2020) siswa berkemampuan sedang memfokuskan perhatian pada informasi, dengan begitu siswa mampu menghubungkan pengetahuan yang sudah ada dan dapat membedakan apa yang diketahui dan ditanyakan.

SPS kurang mampu memanggil kembali informasi, karena tidak dapat menjelaskan maksud soal menggunakan bahasa sendiri. SPS belum pernah mendapatkan soal serupa. Uraian tersebut menjelaskan bahwa SPS tidak mampu menafsirkan informasi (persepsi) dengan mengetahui hubungan antara pengetahuan terdahulu dan informasi yang diterima. Sesuai pendapat Slavin (2008) bahwa keadaan pikiran yang berasal dari pengalaman masa lampau, pengetahuan, dorongan dari dalam diri sendiri atau motivasi, serta faktor lainnya mempengaruhi persepsi siswa dan melibatkan penafsiran pikiran. Apabila pengalaman yang dimiliki siswa kurang, maka siswa akan mengalami kesulitan saat memanggil kembali informasi.

2. Merencanakan Penyelesaian

SPS dapat memanggil kembali informasi dengan mengingat konsep, rumus, serta aturan yang dikuasai untuk menyusun rencana penyelesaian dengan tepat. Konsep dan aturan yang disebutkan adalah SPLDV, operasi bentuk aljabar, menyusun suatu persamaan.

Tabel 3. 8 Wawancara SPS Tahap merencanakan penyelesaian

\begin{tabular}{|c|l|}
\hline Kode & \multicolumn{2}{|c|}{ Kegiatan } \\
\hline PSPS $_{2}$ & $\begin{array}{l}\text { Jelaskan bagaimana kamu menggunakan } \\
\text { konsep yang sudah kamu sebutkan } \\
\text { sebelumnya untuk menyelesaikan masalah? }\end{array}$ \\
\hline JSPS $_{2}$ & $\begin{array}{l}\text { Pertama saya mencari persamaan mbak, yang } \\
\text { mau dicari kan pensil sama penggaris mbak, }\end{array}$ \\
\hline
\end{tabular}

\begin{tabular}{|l|l|}
\hline & $\begin{array}{l}\text { persamaan pertama itu pensilnya ada 2 } \\
\text { penggarisnya 5 harganya itu } 18.500 \text { dicari } \\
\text { dari total harga dikurangi kembalian } \\
\text { dikurangi harga penghapus, terus persamaan } \\
\text { kedua itu 2 pensil sama 1 penggaris harganya } \\
8.000 \text { mbak }\end{array}$ \\
\hline PSPS $_{3}$ & $\begin{array}{l}\text { Sebelum menggunakan rencana saat ini, } \\
\text { apakah ada rencana lain yang digunakan? }\end{array}$ \\
\hline JSPS $_{3}$ & $\begin{array}{l}\text { Sebenarnya SPLDV saja mbak tapi saya } \\
\text { mencoba berkali-kali sampai persamaan tadi } \\
\text { susah memahami soalnya mbak. }\end{array}$ \\
\hline
\end{tabular}

slip:

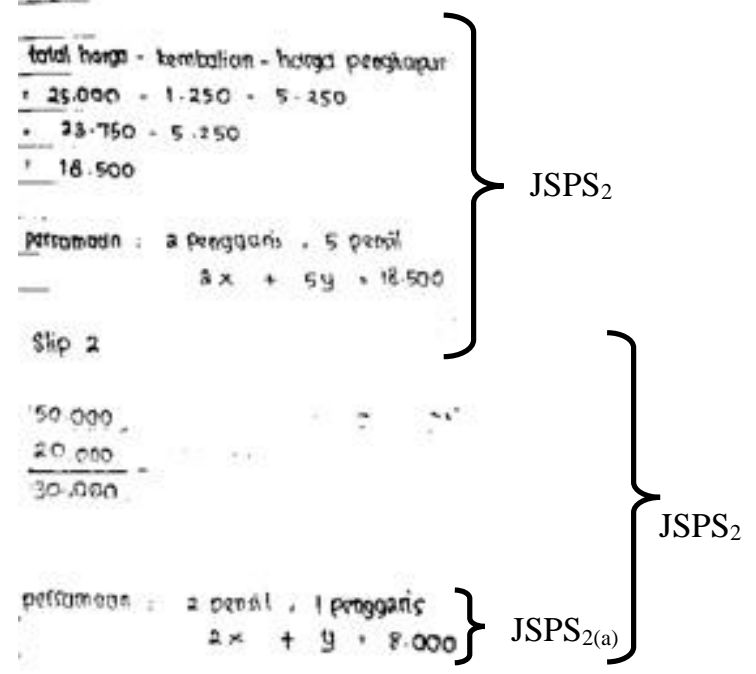

Gambar 3. 14 Lembar jawaban SPS pada TPMMK

Berdasarkan tabel 3.8, SPS menjelaskan ide atau langkah yang akan digunakan untuk memecahkan masalah dengan mengaitkan pengetahuan yang dimiliki sebelumnya yaitu menyusun persamaan melalui kedua slip yang disajikan, dilihat dari gambar 3.14, SPS membuat pemisalan untuk penggaris, penghapus, pensil, dan sampul plastik, kemudian menentukan harga untuk 2 penggaris dan 5 pensil melalui informasi pada slip 1, kemudian mencari harga untuk 2 pensil dan 1 penggaris dengan melihat informasi pada slip $2\left(\mathrm{JSPS}_{2}\right)$, tetapi persamaan yang diperoleh kurang tepat karena pemisalan yang diberikan tidak sesuai (JSPS 2(a)). Hal tersebut didukung oleh sebuah penelitian yang menyatakan siswa berkemampuan matematika sedang memanggil kembali informasi dengan menyebutkan pengetahuan terdahulu yang dimiliki siswa (Isroil et al., 2017). Saat membuat model matematika siswa mengalami kesalahan hal ini dapat disebabkan karena siswa kurang teliti dan mengalami lupa, sesuai dengan hasil penelitian Kusaeri et al., (2018) siswa yang kurang teliti dan mengalami lupa dapat membuat kesalahan konsep atau perhitungan yang dihasilkan. SPS mengungkapkan bahwa rencana yang saat ini digunakan merupakan hasil dari beberapa kali percobaan saat memahami masalah (JSPS 3 ). 


\section{Melaksanakan Rencana Penyelesaian}

SPS dapat memanggil kembali informasi dengan mengingat informasi penting yaitu bahwa jumlah barang dan harga pada slip digunakan untuk menyelesaikan masalah, menggunakan ide yang telah direncanakan untuk menyelesaikan masalah dengan tepat sehingga menghasilkan jawaban benar, sesuai dengan hasil penelitian Purwanto et al., (2019), pengalaman atau pengetahuan sebelumnya yang dimiliki siswa akan dihubungkan dengan situasi-situasi pada masalah matematika yang sedang diselesaikan.

Tabel 3. 9 Wawancara SPS Tahap melaksanakan rencana

\begin{tabular}{|c|l|}
\hline Kode & \multicolumn{1}{|c|}{ Kegiatan } \\
\hline PSPS $_{4}$ & $\begin{array}{l}\text { Ceritakan langkah penyelesaian yang telah } \\
\text { kamu kerjakan? }\end{array}$ \\
\hline & $\begin{array}{l}\text { Dua persamaan tadi saya eliminasi, setelah } \\
\text { ketemu nilai y nya kan 2.500 terus saya } \\
\text { masukkan ke persamaan 2x+5y = 18.500, } \\
\text { ketemu mbak x nya 3.000. berarti kalau Ani } \\
\text { mau beli satu penggaris sama satu pensil } \\
\text { harus bayar 5.500 mbak harganya } \\
\text { dijumlahkan. }\end{array}$ \\
\hline PSPS $_{5}$ & Langkah eliminasinya dimana? \\
\hline JSPS $_{5}$ & Oiyaa saya lupa mbak. \\
\hline
\end{tabular}

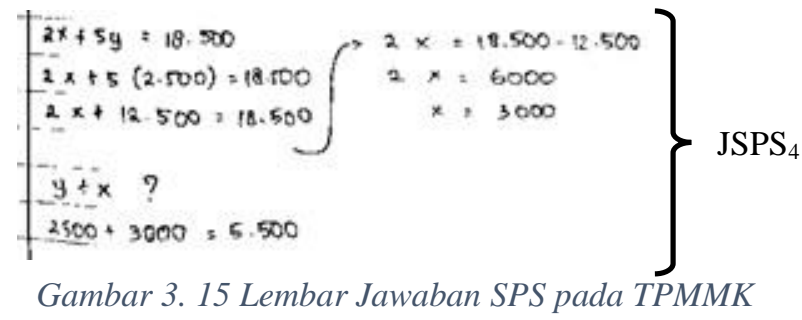

Berdasarkan gambar 3.15, SPS dapat mengolah informasi dengan menjelaskan cara yang dilakukan untuk memecahkan masalah (JSPS 4 ), SPS juga mengaitkan rencana penyelesaian dari soal dengan pengetahuan terdahulu, yaitu operasi hitung bilangan, operasi bentuk aljabar, menentukan persamaan melalui masalah kontekstual yang disajikan dan menyajikan masalah kontekstual kedalam bentuk model matematika, yaitu SPLDV, berargumen logis serta dapat memilih dan menerapkan strategi untuk model atau masalah matematika kontekstual dengan tepat, metode yang digunakan adalah eliminasi dan subtitusi, terdapat langkah penyelesaian yang tidak dituliskan sesuai petikan wawancara pada tabel 3.9 ( JSPS $_{5}$ ) karena mengalami lupa, sesuai dengan penelitian Purwanto et al., (2019) siswa dapat mengalami lupa (forgotten lost) dikarenakan konsep yang digunakan untuk mengerjakan soal tidak tersimpan dengan baik di memori jangka panjang.

4. Memeriksa Kembali

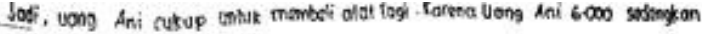 tod horgeng 5000 \\ Gambar 3. 16 Lembar jawaban SPS pada TPMMK}

Berdasarkan gambar 3.16, SPS dapat memanggil kembali informasi dengan membuat kesimpulan bahwa hasil yang didapat sudah menjawab pertanyaan pada soal, secara lisan maupun secara tulisan.

SPS kurang mampu mengolah informasi, karena tidak memeriksa penyelesaian yang telah dilakukan, dan tidak mengetahui hal penting yang harus diperiksa hal itu terlihat di beberapa langkah yang dilakukan sebelumnya seringkali ada kesalahan baik dalam penulisan maupun bagian penting yang tidak dituliskan sehingga SPS tidak mengetahui ada gagasan yang salah. Berdasarkan hasil analisis dan pembahasan, diperoleh skema proses berpikir sebagai berikut;

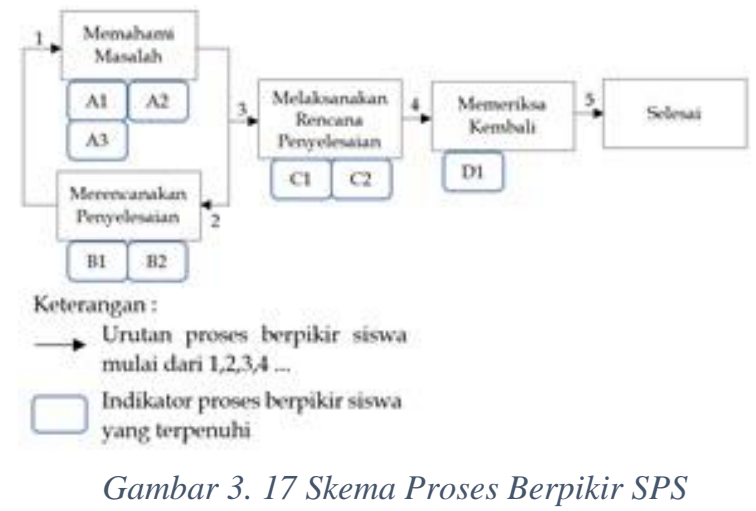

Skema proses berpikir SPS pada gambar 3.17, menjelaskan bahwa SPS melakukan semua tahapan proses berpikir siswa dalam memecahkan masalah dan ada beberapa indikator pada tabel 2.1 yang tidak terpenuhi, SPS mengulangi tahap memahami masalah dan merencakan penyelesaian sebelum melanjutkan tahap berikutnya seperti yang dijelaskan pada tabel 3.8.

\section{Proses berpikir siswa laki-laki berkemampuan matematika rendah (SLR)}

\section{Memahami Masalah}

SLR dapat menerima informasi dengan membaca masalah yang disajikan menggunakan indera dan memahami maksud soal, sjalan dengan pendapat Robert (1995) bahwa siswa memberikan perhatian terhadap soal atau menyadari informasi yang ada disektarnya sehingga informasi tersebut akan diterima oleh panca indera.

SLR dapat memenyimpan informasi dengan membaca soal lebih dari dua kali atau berkali-kali, SLR kesulitan saat memahami soal, yang disebabkan oleh kurangnya pengalaman atau pengetahuan, pernyataan yang mendukung yaitu ketika pengetahuan sesorang semakin banyak, maka semakin mudah pula seseorang dalam 
mengorganisasi informasi baru (Woolfolk 1995). Sedangkan pengalaman yang dimiliki SLR kemungkinan masih kurang untuk digunakan mengerjakan soal.

SLR dapat mengolah informasi dengan mengungkapkan tujuan yang dimaksud soal yaitu menentukan apakah uang Ani cukup untuk membeli pensil dan penggaris, dan dan mengidentifikasi kecukupan data dengan cara memaparkan hal yang ditanyakan dan diketahui pada soal secara lisan.

SLR kurang mampu memanggil kembali informasi, tidak dapat menjelaskan maksud dalam soal dengan bahasa sendiri, SLR hanya membaca kembali soal dan menyebutkan apa yang ditanyakan. Selain itu SLR kurang mampu memperlihatkan hubungan antara pengetahuan yang dimiliki dengan penyelesaian masalah yang dilakukan. SLR mengungkapkan tidak pernah mendapat soal yang serupa sebelumnya. Hal ini disebabkan karena SLR mengalami gangguan di dalam pikirannya, SLR mengalami kegagalan saat memanggil kembali informasi yang dimiliki. Sesuai penelitian Putra (2017) bahwa siswa tidak mampu memanggil kembali informasi yang dimiliki karena terjadinya fragmented atau tidak saling terhubungnya konsep yang tersimpan di memori jangka panjang.

2. Merencanakan Penyelesaian

Tabel 3. 10 Wawancara SLR Tahap merencanakan penyelesaian

\begin{tabular}{|c|l|}
\hline Kode & \multicolumn{1}{|c|}{ Kegiatan } \\
\hline PSLR $_{1}$ & $\begin{array}{l}\text { Menurut kamu adakah keterkaitan soal ini } \\
\text { dengan topik atau materi yang lain? Kalau } \\
\text { ada materi apa? }\end{array}$ \\
\hline JSLR $_{1}$ & SPLDV mbak \\
\hline PSLR $_{2}$ & $\begin{array}{l}\text { Jelaskan bagaimana kamu menggunakan } \\
\text { konsep yang sudah kamu sebutkan } \\
\text { sebelumnya untuk menyelesaikan masalah? }\end{array}$ \\
\hline JSLR $_{2}$ & $\begin{array}{l}\text { Itu mbak dibuat ada 2 penggaris 5 pensil } \\
\text { sama dengan 18.500 terus 1 penggaris sama } \\
2 \text { pensil sama dengan 8.000 }\end{array}$ \\
\hline PSLR $_{3}$ & $\begin{array}{l}\text { Dari mana dek kamu dapatkan itu } \\
\text { (persamaan)? }\end{array}$ \\
\hline JSLR $_{3}$ & $\begin{array}{l}\text { Emm yaitu mbak dikali satu satu penggaris } \\
\text { ditambah 2 pensil sama dengan 8.000 }\end{array}$ \\
\hline PSLR $_{4}$ & $\begin{array}{l}\text { Kenapa tidak menggunakan pemisalan } \\
\text { seperti penggaris dimisalkan dengan variabel } \\
x, \text { pensil dimisalkan dengan variabel } y ?\end{array}$ \\
\hline JSLR $_{4}$ & \begin{tabular}{l} 
Iya mbak itu penggarisnya $x$, pensilnya $z$ \\
\hline
\end{tabular}
\end{tabular}

Berdasarkan tabel 3.10, SLR kurang mampu memanggil kembali informasi, menyebutkan konsep, rumus, serta aturan yang digunakan untuk memecahkan masalah yaitu SPLDV namun konsep yang disebutkan SLR tidak lengkap (JSLR ${ }_{1}$ ).

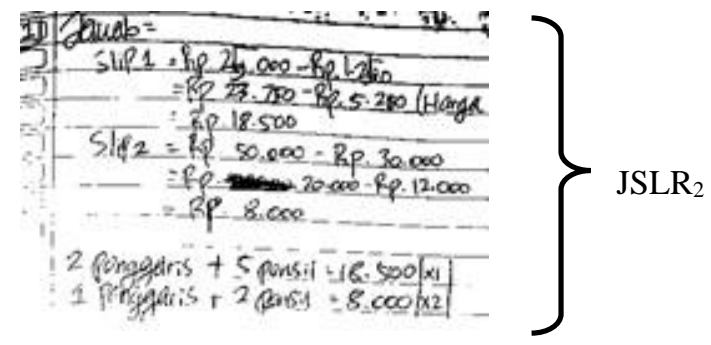

Gambar 3. 18 Lembar jawaban SLR pada TPMMK

SLR kurang mampu mengolah informasi, terlihat bahwa SLR menguraikan jawaban pada gambar 3.18, namun tidak dapat menjelaskan ide atau langkah yang akan digunakan untuk memecahkan masalah dengan mengaitkan pengetahuannya dengan informasi yang ada pada soal, dapat dilihat dari tabel $3.10\left(\right.$ JSLR $_{2}$ dan JSLR 4 ). SLR tidak mengetahui dari mana persamaan yang diperoleh $\left(\mathrm{JSLR}_{3}\right)$. Sesuai dengan penelitian yang menyatakan bahwa siswa yang tidak mampu memeriksa kembali konsep yang dibutuhkan disebabkan karena siswa kurang baik menyimpan pengetahuan dan pengalaman yang digunakan dalam menyelesaikan masalah matematika. Berdasarkan hal tersebut siswa tidak mampu menjelaskan dengan baik hasil pekerjannya (Amamah et al., 2016)

3. Melaksanakan Rencana Penyelesaian

Tabel 3.11 Wawancara SLR Tahap melaksanakan rencana

\begin{tabular}{|c|l|}
\hline Kode & \multicolumn{1}{|c|}{ Kegiatan } \\
\hline PSLR $_{5}$ & $\begin{array}{l}\text { Informasi penting apa saja yang kamu } \\
\text { gunakan untuk menyelesaikan soal? }\end{array}$ \\
\hline SSLR $_{5}$ & $\begin{array}{l}\text { Udah ini mbak di slipnya } R p 25.000 \text { tunai, } \\
\text { kembalian } R p 1.250 \text { terus dikurangi hasilnya } \\
R p 23.750, \text { harga penghapus 5.250 itu } \\
\text { dikurangi hasilnya 18.500 }\end{array}$ \\
\hline PSLR $_{6}$ & $\begin{array}{l}\text { Ceritakan langkah penyelesaian yang telah } \\
\text { kamu kerjakan? }\end{array}$ \\
\hline JSLR $_{6}$ & $\begin{array}{l}\text { Itu mbak dikalikan 1 sama dua terus hasilnya } \\
\text { pensil 2.500 } \\
\text { Terus dikalikan 2 sama 5 hasilnya penggaris } \\
\text { 3.000 }\end{array}$ \\
\hline PSLR $_{7}$ & $\begin{array}{l}\text { Kenapa kamu kalikan persamaan-persamaan } \\
\text { itu dek? }\end{array}$ \\
\hline JSLR $_{7}$ & $\begin{array}{l}\text { Bingung mbak, susah, jadi bingung } \\
\text { ngitungnya }\end{array}$ \\
\hline PSLR $_{8}$ & $\begin{array}{l}\text { Waktu mengerjakan metode apa? Alasannya } \\
\text { apa menggunakan metode itu? }\end{array}$ \\
\hline JSLR $_{8}$ & \begin{tabular}{l} 
Eliminasi bukan mbak? Hmm bingung mbak \\
\hline
\end{tabular} \\
\hline
\end{tabular}


Berdasarkan tabel 3.11, SLR kurang mampu memangil kembali informasi, karena SLR tidak dapat menyebutkan informasi penting dan ide yang telah direncanakan sebelumnya $\left(\mathrm{JSLR}_{5}\right)$, sehingga memperlihatkan bahwa terdapat gangguan di dalam pikiran siswa saat memecahkan masalah. Berdasarkan hal tersebut Slavin (2008) mengungkapkan bahwa saat informasi yang dimiliki tercampur atau tersingkirkan oleh informasi lain, saat itulah terjadi sebuah gangguan.

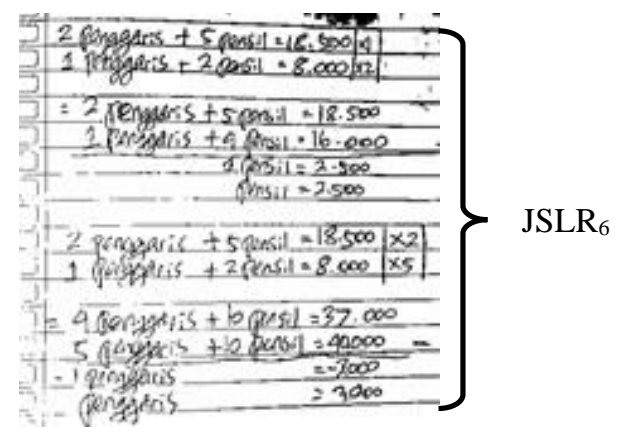

Gambar 3. 19 Lembar jawaban SLR pada TPMMK

Dalam mengolah informasi, SLR menuliskan jawaban pada gambar 3.19 namun tidak dapat menjelaskan penyelesaian yang telah diperoleh $\left(\mathrm{JSLR}_{6}\right)$. SLR tidak dapat mengaitkan rencana penyelesaian dari soal dengan pengetahuan terdahulu secara tepat. Selain itu, SLR kurang mampu memberikan argumen logis $\left(\mathrm{JSLR}_{7}\right)$, kurang mampu mengungkap strategi atau metode yang digunakan $\left(\mathrm{JSLR}_{8}\right)$. Hal tersebut ditunjang oleh pendapat Kusaeri et al., (2018) bahwa siswa tidak melakukan pemanggilan kembali dengan tepat sehingga respon yang diperoleh tidak tepat dan solusi tidak saling terkait. Penyebab jawaban siswa yang salah yaitu konsep-konsep yang dibutuhkan tidak terekam oleh memori siswa.

4. Memeriksa Kembali

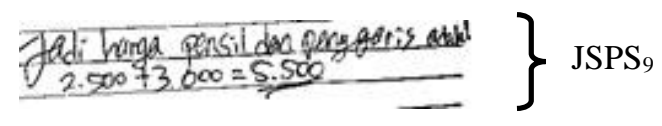

Gambar 3. 20 Lembar jawaban SLR pada TPMMK

Berdasarkan gambar 3.20, SLR dapat memanggil kembali informasi dengan membuat kesimpulan bahwa hasil yang didapat sudah menjawab pertanyaan pada soal, secara lisan maupun tulisan yaitu harga pensil dan penggaris adalah $R p 5.500$ ( JSLR $\left._{9}\right)$.

SLR kurang mampu mengolah informasi, walaupun memeriksa kembali hasil yang telah diperoleh namun tidak dapat menjelaskan bagian yang perlu dicek ulang dan mengalami kebingungan saat ditanya mengenai kesimpulan yang diperoleh, dikarenakan SLR tidak menguasai konsep yang digunakan untuk menyelesaikan masalah dengan baik ditunjang oleh hasil penelitian Kusaeri et al., (2018) siswa berkemampuan matematika rendah tidak mampu melakukan pemanggilan kembali dengan tepat sehingga solusi tidak relevan dan respon yang didapatkan salah. Respon siswa yang salah disebabkan karena konsep-konsep yang dibutuhkan tidak tersimpan dengan baik dalam memori siswa. Berdasarkan hasil analisis dan pembahasan, dapat diperoleh skema proses berpikir sebagai berikut;

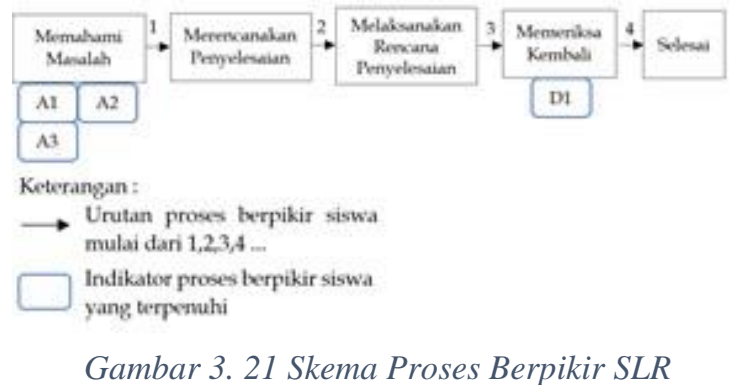

Skema proses berpikir SLR pada gambar 3.21, menjelaskan bahwa SLR melakukan semua tahapan proses berpikir siswa dalam memecahkan masalah dan sebagian besar indikator pada tabel 2.1 tidak terpenuhi.

\section{Proses berpikir siswa perempuan berkemampuan matematika rendah (SPR)}

1. Memahami Masalah

Tabel 3. 12 Wawancara SPR Tahap memahami masalah

\begin{tabular}{|c|l|}
\hline Kode & \multicolumn{1}{|c|}{ Kegiatan } \\
\hline PSPR $_{1}$ & $\begin{array}{l}\text { Informasi apakah yang kamu peroleh dari } \\
\text { soal? }\end{array}$ \\
\hline JSPR $_{1}$ & $\begin{array}{l}\text { Slip satu itu ada 2 penggaris tapi itu tidak } \\
\text { diketahui harganya, kalau yg penghapus itu, } \\
\text { penghapus 3 terus harganya 5.250 kalau } \\
\text { pensil itu jumlahnya 5 tapi tidak diketahui } \\
\text { harganya, terus sama ini tunai belanja sama } \\
\text { kembaliannya }\end{array}$ \\
\hline
\end{tabular}

SPR dapat menerima informasi dengan membaca masalah melalui indera dan mampu memahami masalah, sesuai dengan pendapat Robert (1995) bahwa siswa memberikan perhatian terhadap soal atau menyadari informasi yang ada disekitarnya sehingga informasi tersebut akan diterima oleh panca indera.

SPR dapat menyimpan informasi dengan membaca soal berkali-kali. Hal tersebut memperlihatkan bahwa SPR memiliki kesulitan saat memahami soal, pernyataan yang mendukung yaitu ketika pengetahuan sesorang semakin banyak, maka semakin mudah pula seseorang dalam mengorganisasi informasi baru (Woolfolk 1995). SPR memerlukan beberapa kali kesempatan karena pengetahuan dan pengalman yang dimiliki masih kurang.

Berdasarkan tabel 3.12, SPR dapat mengolah informasi dengan menyebutkan tujuan dan mengidentifikasi kecukupan data dengan cara memaparkan hal yang ditanyakan dan diketahui pada soal 
secara lisan untuk menyelesaikan masalah kontekstual yang disajikan (JSLR 1 ).

SPR kurang mampu memanggil kembali informasi, karena kurang mampu mnejelaskan dengan lengkap maksud soal menggunakan bahasa sendiri. SPR hanya menguraikan apa yang ditanyakan. Selain itu SPR tidak menggunakan dan menghubungkan pengetahuan yang dimilki. Hal ini disebabkan karena SPR mengalami gangguan di dalam pikirannya, SPR mengalami kegagalan saat memanggil kembali informasi yang dimiliki. Sesuai dengan penelitian Putra (2017) yang menjelaskan bahwa siswa tidak mampu memanggil kembali informasi yang dimiliki karena terjadinya fragmented atau tidak saling terhubungnya konsep yang tersimpan di memori jangka panjang (long term memory).

2. Merencanakan Penyelesaian

SPR kurang mampu memanggil kembali informasi, karena konsep, rumus, serta aturan yang disebutkan kurang lengkap, SPR hanya menyebutkan SPLDV.

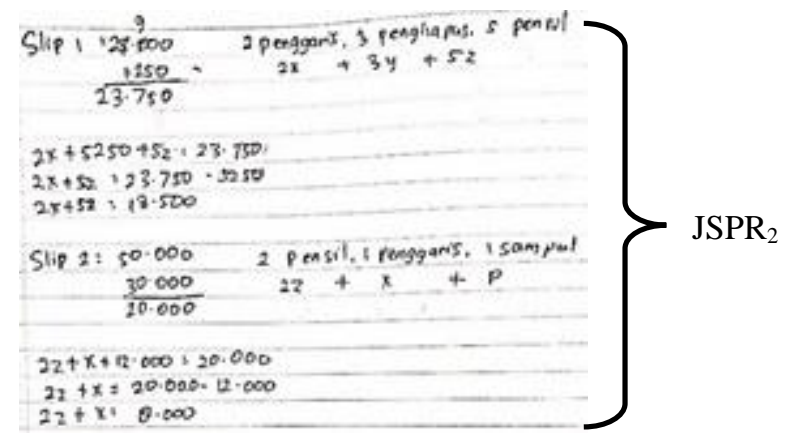

Gambar 3. 22 Lembar jawaban SPR pada TPMMK

SPR mampu mengolah informasi dengan cara menguraikan ide atau langkah yang akan digunakan untuk memecahkan masalah dengan mengaitkan pengetahuan yang dimiliki sebelumnya yaitu menyusun persamaan melalui kedua slip yang disajikan, dilihat dari gambar 3.22, SPR membuat pemisalan untuk penggaris, penghapus, pensil, dan sampul plastik, kemudian menentukan harga untuk 2 penggaris dan 5 pensil dengan melihat informasi pada slip 1 kemudian mencari harga untuk 2 pensil dan 1 penggaris dengan melihat informasi pada slip $2\left(\mathrm{JSPR}_{2}\right)$.

3. Melaksanakan Rencana Penyelesaian

Tabel 3.13 Wawancara SPR tahap melaksanakan rencana

\begin{tabular}{|c|l|}
\hline Kode & \multicolumn{1}{|c|}{ Kegiatan } \\
\hline PSPR $_{3}$ & $\begin{array}{l}\text { Ceritakan langkah penyelesaian yang telah } \\
\text { kamu kerjakan? }\end{array}$ \\
\hline $\mathrm{JSPR}_{3}$ & $\begin{array}{l}\text { Aku pakai eliminasi sama subtitusi jadi yg } \\
\text { pertama itu dieliminasi terus yang kedua di } \\
\text { subtitusikan ketemu hasilnya 5.500 mbak. } \\
\text { Tapi awalnya saya salah hitung di } \\
\text { eliminasinya bingung terus saya cek lagi } \\
\text { sampai ketemu itu hasilnya mbak. }\end{array}$ \\
\hline
\end{tabular}

\begin{tabular}{|l|l|}
\hline $\mathrm{PSPR}_{4}$ & $\begin{array}{l}\text { Kenapa kamu kalikan persamaan-persamaan } \\
\text { itu dek? }\end{array}$ \\
\hline $\mathrm{JSPR}_{4}$ & Untuk mencari harganya mbak. \\
\hline
\end{tabular}

SPR dapat memanggil kembali informasi dengan menjelaskan bahwa semua informasi yang ada di slip 1 dan 2 digunakan untuk membuat persamaan, dan menggunakan ide yang telah direncanakan untuk menyelesaikan masalah dengan tepat sehingga menghasilkan jawaban benar, sesuai dengan hasil dari sebuah penelitian bahwa subjek melaksanakan rencana berdasarkan data yang ditemukan sebelumnya dan menuliskan langkah-langkah penyelesaian sesuai rencana (Listanti et al., 2020).

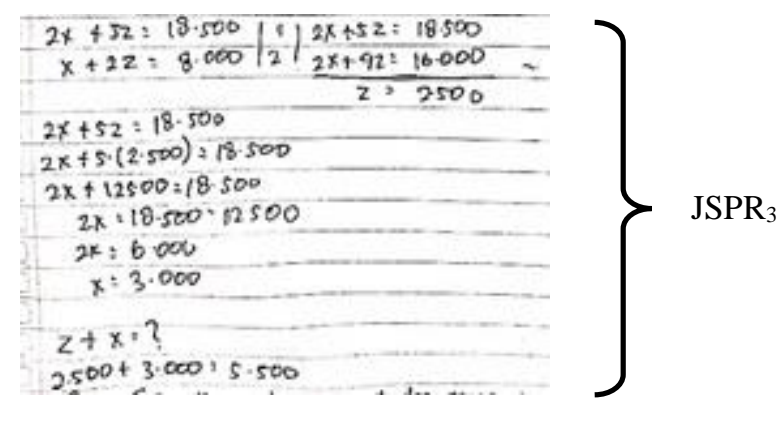

Gambar 3. 23 Lembar jawaban SPR pada TPMMK

SPR dapat mengolah informasi dengan menjelaskan cara yang dilakukan untuk memecahkan masalah, mengaitkan rencana penyelesaian dari soal dengan pengetahuan terdahulu, berdasarkan gambar 2.23 yaitu operasi hitung bilangan, operasi bentuk aljabar, menentukan persamaan melalui masalah kontekstual yang disajikan dan menyajikan masalah kontekstual kedalam bentuk model matematika, yaitu SPLDV, sesuai petikan wawancara pada tabel 3.13, SPR mengungkapkan mengalami kesulitan saat melaksanakan rencana dan memeriksa kembali penyelesaiannya, SPR mampu berargumen logis, menerapkan strategi dan atau metode eliminasi dan subtitusi untuk menyelesaikan masalah $\left(\mathrm{JSPR}_{3}\right.$ dan $\left.\mathrm{JSPR}_{4}\right)$, SPR mengungkapkan sudah terbiasa menggunakan metode tersebut. Hal ini sesuai dengan hasil penelitian Purwanto et al., (2019), pengalaman atau pengetahuan sebelumnya yang dimiliki siswa akan dihubungkan dengan situasi-situasi pada masalah matematika yang sedang diselesaikan.

\section{Memeriksa Kembali}

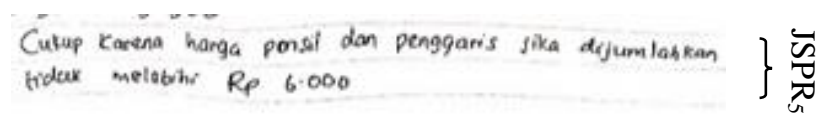

Gambar 3. 24 Lembar jawaban SPR pada TPMMK

Berdasarkan gambar 3.24, SPR dapat memanggil kembali informasi, mampu membuat kesimpulan dari masalah kontekstual, SPR mengungkapkan hasil yang 
didapat sudah menjawab pertanyaan baik secara lisan maupun tulisan $\left(\mathrm{JSPR}_{5}\right)$

SPR dapat mengolah informasi dengan memeriksa kembali penyelesaian yang diperoleh dan mengetahui gagasan yang salah, mengetahui hal penting yang harus diperiksa yaitu perhitungan eliminasinya. Berdasarkan hasil analisis dan pembahasan, diperoleh skema proses berpikir sebagai berikut;

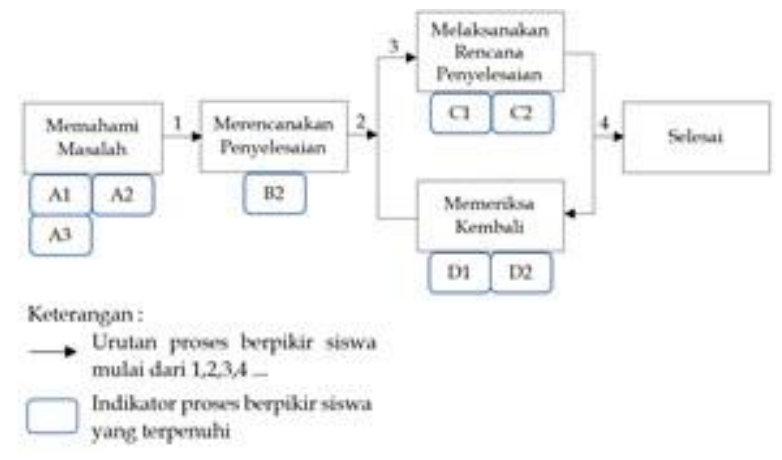

Gambar 3. 25 Skema Proses Berpikir SPR

Skema proses berpikir SPR pada gambar 3.25, menjelaskan bahwa SPR melakukan semua tahapan proses berpikir siswa dalam memecahkan masalah dan ada beberapa indikator pada tabel 2.1 yang tidak terpenuhi, SPR mengulangi tahap melaksanakan rencana penyelesaian dan memeriksa kembali sebelum akhirnya memperoleh penyelesaian seperti yang terdapat pada tabel 3.13 .

\section{PENUTUP}

\section{Simpulan}

Bersumber dari hasil penelitian dan pembahasan, menerangkan adanya perbedaan proses berpikir antara siswa laki-laki dan perempuan pada masing-masing kategori kemampuan matematika tinggi, sedang, dan rendah yaitu pada urutan proses berpikir, tahapan pemecahan masalah dan tahapan proses berpikir yang dilakukan siswa. Siswa berkemampuan matematika tinggi melakukan seluruh tahapan proses berpikir berdasarkan indikator proses berpikir siswa dalam memecahkan masalah kontekstual, yaitu pada tahap memahami masalah, siswa melalui proses berpikir menerima, menyimpan, mengolah, dan memanggil kembali informasi, pada tahap merencanakan penyelesaian, melaksanakan rencana penyelesaian dan memeriksa kembali, siswa melalui proses berpikir memanggil kembali dan mengolah informasi, namun urutan proses berpikir berbeda, siswa laki-laki mengulangi tahap melaksanakan penyelesaian dan memeriksa kembali, kemudian selesai, sedangkan siswa perempuan mengulangi proses memahami masalah, dan merencakan penyelesaian, saat kedua tahap tersebut selesai, siswa mengulangi dua tahap melaksanakan rencana penyelesaian, dan memeriksa kembali. Siswa berkemampuan matematika sedang dengan jenis kelamin laki-laki ketika memahami masalah, tidak memanggil kembali informasi, tahap melaksanakan rencana penyelesaian tidak mengolah informasi, kemudian kembali lagi ke tahap merencanakan masalah, dan selesai sedangkan siswa perempuan memahami masalah tanpa memanggil kembali informasi, mengulangi tahap merencanakan penyelesaian dam memahami masalah, pada tahap memeriksa kembali, siswa tidak memanggil kembali informasi. Siswa berkemampuan matematika rendah berjenis kelamin laki-laki memahami masalah tanpa memanggil kembali informasi, merencanakan penyelesaian, dan melaksanaan rencana penyelesaian tanpa memanggil kembali informasi maupun mengolah informasi, tahap selanjutnya yaitu memeriksa kembali tanpa mengolah informasi sedangkan siswa perempuan melalui tahap memahami masalah dan merencakan masalah tanpa memanggil kembali informasi, siswa mengulangi tahap melaksanakan rencana penyelesaian dan memeriksa kembali.

\section{Saran}

Berdasarkan kesimpulan yang diperoleh, terdapat perbedaan proses berpikir siswa berdasarkan kemampuan matematika dan jenis kelamin, sehingga guru disarankan untuk menyusun metode pembelajaran yang sesuai bagi siswa agar siswa dengan berbagai macam kemampuan matematika, dan jenis kelamin dapat memahami materi pelajaran yang diberikan, serta mampu meningkatkan kemampuan berpikir matematika. Bagi peneliti lain yang akan melakukan penelitian relevan dengan penelitian ini, diharapkan mampu mengungkap lebih dalam mengenai proses berpikir siswa dengan subjek dan tinjauan yang berbeda.

\section{DAFTAR PUSTAKA}

Alifah, N., \& Aripin, U. (2018). Proses Berpikir Siswa SMP dalam Memecahkan Masalah Matematik ditinjau dari Gaya Kognitif Field Dependet dan Field Independent. 1(4), 505-512.

Amamah, S., Sa'dijah, C., \& Sudirman. (2016). Proses Berpikir Siswa SMP Bergaya Kognitif Field Dependent dalam Menyelesaikan Masalah Berdasarkan Teori Pemrosesan Informasi. 237245.

Asfar, A. I. T., \& Nur, S. (2018). Model pembelajaran problem posing \& solving: meningkatkan kemampuan pemecahan masalah. CV Jejak (Jejak Publisher). 
De Lange, J. (1987). Mathematics_Insight and Meaning, OW \& OC, Utrecht. De LangeMathematicsInsight and Meaning 1987.

Fajriati, M. (2019). Proses Kognitif Siswa dalam Memecahkan Masalah Matematika ditinjau dari Kemampuan Matematika MATHE dunesa., 7(3),21-29.

Fauziyah, N., Budayasa, I. K., \& Juniati, D. (2020). Differences in the Cognitive Processes of Autism Spectrum Disorder Student in Understanding Mathematical Problems Based on the Level of Intelligence. International Journal of Psychosocial Rehabilitation, Vol. 24, Issue 06.

Ganley, C. M., \& Vasilyeva, M. (2011). Sex differences in the relation between math performance, spatial skills, and attitudes. Journal of Applied Developmental Psychology, 32(4), 235-242. https://doi.org/10.1016/j.appdev.2011.04.001

Gravemeijer, K., \& Doorman, M. (1999). Context problems in realistic mathematics education: A calculus course as an example. Educational studies in mathematics, 39(1-3), 111-129.

Isroil, A., Budayasa, I. K., \& Masriyah, M. (2017). Profil Berpikir Siswa SMP dalam Menyelesaikan Masalah Matematika Ditinjau dari Kemampuan Matematika. Jurnal Review Pembelajaran Matematika, 2(2), 93105. https://doi.org/10.15642/jrpm.2017.2.2.93-105

Jayanti, M. D., Irawan, E. B., \& Irawati, S. (2018). Kemampuan Pemecahan Masalah Kontekstual Siswa SMA pada Materi Barisan dan Deret. Jurnal Pendidikan Matematika, 3(5), 671-678.

Kartono dan Kartini. (1989). Psikologi Wanita (Jidil I): Mengenal Gadis Remaja dan Wanita Dewasa. Bandung: CV Mandar Maju.

Kusaeri, Lailiyah, S., Arrifadah, Y., \& Hidayati, N. (2018). Proses Berpikir Siswa dalam Menyelesaikan Masalah Matematika Berdasarkan Teori Pemrosesan Informasi. 4(2), 125-141.

Listanti, D. R., Mampouw, H. L., Kristen, U., \& Wacana, S. (2020). Profil pemecahan masalah geometri oleh siswa smp ditinjau dari perbedaan kemampuan matematika. 04(01), 365-379.

Moleong, L. J. (2012). Metodologi penelitian kualitatif. Bandung: Remaja Rosdakaya. NCTM. (2000). Principles and standards for school mathematics. Reton, VA: NCTM, Inc.

Ngilawajan, D. A. (2013). PROSES BERPIKIR SISWA SMA DALAM FIELD INDEPENDENT DAN FIELD DEPENDENT. 2(1), 71-83.

Nurhayati, Huda, N., \& Suratno. (2020). Analisis Pemecahan Masalah Berdasarkan Teori Pemrosesan Informasi. 10(September), 136-143. https://doi.org/10.33087/dikdaya.v10i2.169
Panjaitan, B. 2016. Proses Kognitif Siswa Dalam Memecahkan Masalah Matematika. Jurnal Ilmu Pendidikan. Vol. 19(1): hal. 17-25.

Parulian, R. A. (2019). Analisis Kemampuan Pemecahan Masalah Matematis Dalam MenyelesaikanMateri Bilangan Bulat Pada Siswa SMP. 345-354.

Polya, G. (1973). How to Solve It. Garden City: Doubleday.

Purwanto, W. R., Sukestiyarno, Y. L., \& Junaedi, I. (2019). Proses Berpikir Siswa dalam Memecahkan Masalah Matematika Ditinjau dari Persepektif Gender.

Putra, D. B. P.dkk. (2017). Proses Berpikir Mahasiswa Teknik Informatika dalam Menyelesaikan Statistika Berdasarkan Teori Pemrosesan Informasi. Jombang: Universitas Hasyim Asy'ari.

Robert L Solso. 1995. Cognitive Psychology. Needham Heights: Allyn \& Bacon

Rosyada, A. (2018). Profil Pemecahan Masalah Matematika Kontekstual Terbuka Siswa ditinjau dari Gaya Kognitif Reflektif dan Implusif. MATHE dunesa. 7(2), 299-307.

Syafitri T, Subanji, \& Dwiyana. (2016). Proses Berpikir Siswa Tunanetra Dalam Menyelesaikan Masalah Matematika Ditinjau Dari Teori Pemrosesan Informasi. Jurnal Pendidikan, 1(7), 1265-1278. https://doi.org/10.17977/jp.v1i7.6528

Slavin, Robert. E. (2006). Educational Pyschology: Theory and Practice (8th edition). Boston: Pearson Education, Inc. Hal 167.

Slavin, Robert. E. (2008). Psikologi Pendidikan: Teori dan Praktik. Edisi 8. Jilid 1. Terjemahan Marianto Samosir. Jakarta: Macanan Jaya Cemerlang.

Soedjadi, R. (2000). Kiat pendidikan matematika di Indonesia: konstatasi keadaan masa kini menuju harapan masa depan. Direktorat Jenderal Pendidikan Tinggi, Departemen Pendidikan Nasional.

Solso, R.L.M, Otto, H. \& Maclin, M.K. (2008). Psikologi Kognitif Edisi Kedelapan. Jakarta: Erlangga.

Tanjung, M. P. (2018). Proses Berpikir Siswa SMP Dalam Menyelesaikan Masalah Kontekstual Aritmetika Sosial Ditinjau Dari Perbedaan Jenis Kelamin. MATHEdunesa, 7(2), 393=397.

Trifatmasari, M., \& Kurniasari, I. (2016). Proses Berpikir Siswa dalam Memecahkan MasalahMatematika Kontekstual Ditinjau dari Tingkat Kemampuan Matematika Siswa pada Materi Lingkaran di Kelas VIII SMP. Jurnal Ilmiah Pendidikan Matematika, 3.

Woolfolk, A. 1995. Educational Psychology. (6 ${ }^{\text {th }}$ ed). Boston, MA: Allyn \& Bacon. 